\title{
Judicial Deference, Agency Commitment, and Force of Law
}

\author{
RICHARD W. MURPHY*
}

The law governing judicial deference to agency statutory constructions is a ghastly brew of improbable fictions and proceduralism. One reason this state of affairs persists is that courts have failed to resolve a contradiction between two competing, sensible impulses in deference doctrine. Oceans of precedent over the last 150 years have stressed that courts should defer to longstanding, reasonable constructions by agencies of statutes they administer. Then along came Chevron, which extolled agency flexibility and instructed courts to extend strong deference even to interpretive flipflops. Competition between the virtues of interpretive consistency and flexibility has bubbled through and confused judicial deference analysis ever since. The Supreme Court's recent efforts to limit the scope of Chevron's strong deference to those agency constructions carrying the "force of law" has worsened such confusion, in part because the Court's discussion and application of this concept were incoherent.

This Article proposes a new "commitment" approach to this "force of law" limitation that has deep roots in the concept of the "rule of law" and considerable power to clarify deference doctrine by resolving the clash between the competing values of interpretive consistency and flexibility. For the rule of law to be genuine, the default position must be that "laws" have general applicability-in other words, the law for X should be the law for $\mathrm{Y}$ as well. This truism suggests that an agency's statutory construction properly can enjoy the force of law only where the agency has committed to applying its construction consistently across time and parties. Where an agency's construction is longstanding, the agency's commitment to consistent application is self-evident. The puzzle, of course, is to reconcile this commitment approach with Chevron's praise of interpretive flexibility. One solution is to recognize that an agency can genuinely commit to a new interpretation by adopting it in a manner that makes it costly to change course later. Where agencies commit to consistency in this way, there is less need for courts to engage in independent statutory construction to protect rule-of-law values, which should leave courts freer to accept the premise of strong deference that the best way to determine the "meaning" of an agency's statute is to trust the agency's own (rational) construction.

* Visiting Professor (2005-2006), Seton Hall University School of Law; Professor, William Mitchell College of Law. Many thanks to Professors Sidney Shapiro, Mark Seidenfeld, William Jordan III, Ronald Krotoszynski, Peter Oh, Raleigh Levine, and A. John Radsan for helpful discussion and criticism at various stages of this Article's preparation. 
"Actions ... speak louder than words, and the majority ends up giving [the] EPA the very Chevron deference-and more-it says should be denied."1

\section{INTRODUCTION}

The Supreme Court recently managed something remarkable: It made the Chevron doctrine more confusing. In its current form, this cornerstone of modern administrative law instructs that a reviewing court should affirm an agency's reasoned and rational construction of a statute it administers so long as that construction carries the "force of law"-whatever that may mean. ${ }^{2}$ In 2004's Alaska Department of Environmental Conservation v. EPA, all nine justices agreed that the EPA's twenty-one-year-old interpretation of certain Clean Air Act provisions lacked the "force of law" because it had been set forth only in internal guidance memoranda and therefore was not entitled to Chevron treatment. ${ }^{3}$ Here is the jarring bit: A five-justice majority, after stressing that the EPA's construction was "longstanding," 4 affirmed the construction because the agency's "rational interpretation... is surely permissible." 5 This language reeks of Chevron deference. ${ }^{6}$ Its use led the dissent acidly to remark: "So deficient are its statutory arguments that the majority must hide behind Chevron's vocabulary, despite its explicit holding that Chevron does not apply."7

${ }^{1}$ Alaska Dep't. of Envtl. Conservation v. EPA, 540 U.S. 461, 517 (2004) (Kennedy, J., dissenting) (citations omitted) [hereinafter ADEC].

2 United States v. Mead Corp., 533 U.S. 218, 229 (2001) (citing Chevron, U.S.A., Inc., v. Natural Res. Def. Council, Inc., 467 U.S. 837, 842-45 (1984)). The literature on Chevron in both case law and the law reviews is, to put the matter mildly, vast. See STEPHEN G. BREYER ET AL., ADMINISTRATIVE LAW AND REGUlatory POLICY 289 (5th ed. 2002) ("In a remarkably short period, Chevron has become one of the most cited cases in all of American law.").

${ }^{3}$ ADEC, 540 U.S. at 487-88; see also id. at 517 (Kennedy, J., dissenting) (agreeing with majority that Chevron deference should not apply to the EPA's statutory construction).

4 Id. at 487.

${ }^{5}$ Id. at 493 (emphasis added); see also id. at 517 ("[The EPA's] arguments do not persuade us to reject [them] as impermissible"); $i d$. at 493 ("That rational interpretation, we agree, is surely permissible.").

${ }^{6}$ Chevron, U.S.A., Inc. v. Natural Res. Def. Council, Inc., 467 U.S. 837, 843-44 (1984) (holding that courts should approve constructions by agencies of statutes they administer that are "reasonable" or "permissible").

${ }^{7}$ Alaska Dep't of Envtl. Conservation v. EPA, 540 U.S. 461, 517 (2004) (Kennedy, J., dissenting). 
$A D E C$ 's seemingly contradictory treatment of a decades-old agency statutory construction underscores an abiding confusion in deference doctrine that flows from its failure to provide a coherent account of the significance of agency interpretive consistency. Chevron celebrated agency interpretive flexibility by proclaiming that initial agency interpretations are not "instantly carved in stone" and that agencies "must consider varying interpretations and the wisdom of [their] polic[ies] on a continuing basis."8 Reading this remark for all it might be worth, one might conclude that an agency ought to be able to change a statutory construction without triggering stricter judicial review; and, indeed, there is a good deal of case law that adheres to something like this view. ${ }^{9}$ But for over a century preceding Chevron, the case law was replete with opinions that treated administrative consistency as a crucial factor for determining deference. ${ }^{10}$ The common sense behind this stance is powerful: Inconsistency suggests an arbitrary or unsure interpreter upon whom the regulated cannot rely.

The current framework for determining the applicability of Chevron's strong deference sidesteps the problem of balancing the virtues of interpretive flexibility and consistency with an analysis that is instead rooted in a complex mix of fiction and proceduralism. The lead case on this point, 2001 's United States $v$. Mead Corp., ${ }^{11}$ held that strong deference applies where: (a) Congress has "delegated authority to the agency generally to make rules carrying the force of law," and (b) "the agency interpretation claiming deference was promulgated in the exercise of that authority." 12 In other cases, agency constructions should net only Skidmore "deference," which basically instructs courts to exercise independent judgment regarding statutory meaning subject to the weak requirement that they carefully consider agency views for persuasiveness. ${ }^{13}$

${ }^{8}$ Chevron, 467 U.S. at 863-64.

${ }^{9}$ See, e.g., Smiley v. Citibank, N.A., 517 U.S. 735, 742 (1996) (stressing that interpretive "change is not invalidating, since the whole point of Chevron is to leave the discretion provided by the ambiguities of a statute with the implementing agency").

10 See infra Part II.A (discussing the pre-Chevron significance of agency consistency to deference).

11 United States v. Mead Corp., 533 U.S. 218, 226-27 (2001).

12 Id.

13 Id. at 237 (citing Skidmore v. Swift \& Co., 323 U.S. 134, 139 (1944)). Skidmore advised courts that the weight of an agency interpretation in a given case should depend on 'the thoroughness evident in [the agency's] consideration, the validity of its reasoning, its consistency with earlier and later pronouncements, and all those factors which give it power to persuade, if lacking power to control." Skidmore, 323 U.S. at 140. Given such instructions, some might reasonably question whether it is appropriate to characterize Skidmore "deference" as a form of independent judicial review. See, e.g., Thomas W. 
Mead also explained that Congress sometimes delegates "force-of-law" interpretive power to an agency without bothering to say so expressly in a statute. ${ }^{14}$ Congress can signal such an implicit delegation by a variety of means, "as by an agency's power to engage in adjudication or notice-andcomment rulemaking, or by some other indication of a comparable congressional intent." 15 As a practical matter, this morass tends to boil down to the proposition that strong deference presumptively applies to agency constructions produced via notice-and-comment or formal adjudication, but not to those produced with fewer procedural bells and whistles. ${ }^{16}$ Deformities of the Mead framework include: (a) its sheer complexity; (b) its inability to offer a persuasive explanation for why procedure should be the presumptive touchstone of strong deference; (c) its incoherence on the meaning of the "force of law" concept upon which it purports to rely; and (d) its inability to justify the durable, sensible judicial impulse-illustrated recently by $A D E C$ - to extend a form of strong deference to longstanding agency statutory constructions. ${ }^{17}$

This Article submits that these problems could be ameliorated if the framework for determining the scope of strong deference confronted directly

Merrill \& Kristin E. Hickman, Chevron's Domain, 89 Geo. L.J. 833, 855 (2001) ("Skidmore is properly regarded as a deference doctrine because the court cannot ignore the agency interpretation-the court must assess that interpretation against multiple factors and determine what weight they should be given."). This Article nonetheless characterizes Skidmore "deference" as a kind of independent review to stress the point that it instructs courts to adopt the statutory interpretations that they themselves deem best. This characterization fits well with Judge Posner's sensible view that many of the finer discriminations of deference to be found in the case law are functionally meaningless, and that there are really only two meaningfully distinct standards of review: plenary and deferential. United States v. McKinney, 919 F.2d 405, 423 (7th Cir. 1990) (Posner, J., concurring). Plenary review is de novo and requires the reviewing court to use independent judgment to determine a matter as it deems best after giving due regard to the reasoning of a lower court or agency; deferential review checks whether a decision falls within the space where rational minds might disagree. Id. at 422. In this framework, Skidmore "deference" is better regarded as a kind of plenary review, whereas Chevron calls for deferential review for rationality.

${ }^{14}$ Mead, 533 U.S. at 227.

15 Id.

16 It should be stressed at the outset that Mead is complex enough that any attempt to declare what it means (or "boils down to") will likely provoke disagreement. Justice Breyer, in particular, has insisted that Mead does not require "some unspecified degree of formal process" to trigger Chevron deference. Nat'l Cable \& Telecomms. Ass'n v. Brand X Internet Servs., 125 S. Ct. 2688, 2712 (2005) (Breyer, J., concurring).

${ }^{17}$ For an extensive review of lower court cases illustrating the confusion Mead has caused, see Lisa Schultz Bressman, How Mead Has Muddled Judicial Review of Agency Action (Vanderbilt Univ. Law School Pub. Law and Legal Theory, Working Paper No. 05-07, 2005), available at http://ssm.com/abstract=703083. 
the significance of agency consistency. In this spirit, it offers a "new" approach to this issue with roots in mountains of case law and some very old separation-of-powers thinking. This approach counsels that, where an agency adopts an interpretation of its statute that has obvious potential to apply to many parties in varied factual contexts (also known as a "pure" interpretation ${ }^{18}$ ), then this interpretation should net Chevron-strength deference only on the condition that the agency commits to applying it uniformly across time and parties - thus imbuing it with what might fairly be called the "force of law." Consistent with Chevron, an agency need not carve a challenged interpretation in stone to demonstrate such commitment. It must, however, be able to persuade a reviewing court that there are objective grounds for concluding that the interpretation will persist for some reasonable period of time. In other words, before favoring an interpretation with rationality review, a court should satisfy itself that the interpretation will function as a generally applicable law and that it is not merely an expedient for the moment. ${ }^{19}$ Absent such an assurance, the court should ensure stable, relatively disinterested interpretation by determining for itself how best to construe the agency's statute-thus creating a judicial precedent subject to stare decisis norms. ${ }^{20}$

18 The distinction between "pure" questions of law, which abstract away from the facts of a given case, and "mixed" questions of law and fact, which determine whether a legal term captures the facts of a particular case, played a key role in pre-Chevron discussions of deference. For a discussion of this dichotomy, see infra Part II.A.2.

${ }^{19}$ For a recent article that likewise stresses the importance of agency consistency for Chevron deference but to somewhat different effect, see Bressman, supra note 17, at 5659. Professor Bressman suggests a synthesis of recent Supreme Court discussions of Chevron deference that would limit its application to interpretations that are (a) the result of "deliberation" or "careful consideration" and also (b) have "binding" legislative effect or a history of "longstanding" "practical adherence" by the agency. Id. at 59 .

${ }^{20}$ Until very recently, one might have argued that judicial interpretations of agency statutes might make regulatory law too stable. Justice Scalia has forcefully argued that, after a court creates a statutory gloss, "it becomes unlawful for the agency to take a contradictory position; the statute now says what the court has prescribed." United States v. Mead Corp., 533 U.S. 218, 247 (2001) (Scalia, J., dissenting). On this view, independent judicial constructions of agency statutes might cause the "ossification of large portions of our statutory law." Id.

The Supreme Court recently gave a direct response to this charge, holding that "[a] court's prior judicial construction of a statute trumps an agency construction otherwise entitled to Chevron deference only if the prior court decision holds that its construction follows from the unambiguous terms of the statute and thus leaves no room for agency discretion." Nat'l Cable \& Telecomms. Ass'n, 125 S. Ct. at 2700. Combining this approach to stare decisis with this Article's "commitment" approach to Chevron deference leads to the following result: The courts should adopt judicial glosses of an 
The first step in developing this "commitment theory" of strong deference lies in conceding that: (a) if deference doctrines are meaningful, then they alter how courts exercise their judicial power; and (b) courts have an obligation to discharge this power as best they can. It follows that any proper justification for a judge-made deference doctrine should explain why its adoption enables courts to do a better job of wielding their judicial power. More specifically, an effort to explain the limits on the applicability of strong deference should identify those contexts in which courts can do a better job of determining legal "meaning" by adopting rational agency interpretations rather than by exercising their own independent judicial judgments concerning "what the law is." 21

To do so, one needs some sort of account of the comparative benefits of both administrative and judicial decision-making. Chevron offered a sketch of administrative strengths, explaining that agencies are better suited to make the policy choices necessary to resolve genuine ambiguity in statutes they administer because: (a) agencies operating within their regulatory bailiwicks generally enjoy greater expertise than generalist courts; and (b) agencies, due to their connections to the executive branch, are more politically accountable than life-tenured judges. ${ }^{22}$

If one grants that these agency advantages are real, then an obvious question follows: Why should one ever prefer a generalist court's independent construction of an ambiguous agency statute over a rational construction offered by the agency that knows it best? The simple answer favored by the commitment theory is that independent judicial constructions limit executive discretion and, when embedded in a system of precedent, tend to make controlling legal norms more specific and stable. In short, independent judicial review can foster the generality of norms across time and parties commonly associated with the rule of law. ${ }^{23}$

agency's statute to ensure consistent, disinterested interpretation until the agency is able to demonstrate that it has itself produced an interpretation with these rule-of-law virtues.

21 Cf. Marbury v. Madison, 5 U.S. (1 Cranch) 137, 177 (1803) (claiming for the courts the duty "to say what the law is").

22 Chevron, U.S.A., Inc. v. Natural Res. Def. Council, Inc., 467 U.S. 837, 865 (1984). Scholars have identified other benefits of the Chevron regime. For instance, most interpretive questions never make it to the Supreme Court's limited docket; therefore, if courts bear primary responsibility for determining the meaning of an agency's organic statute, there is significant danger that this meaning will vary from circuit to circuit. By ensuring that agencies themselves exercise primary control over meaning, Chevron helps ensure that one construction will apply throughout a federal agency's nationwide jurisdiction. Peter L. Strauss, One-Hundred-Fifty Cases Per Year: Some Implications of the Supreme Court's Limited Resources for Judicial Review of Agency Action, 87 COLUM. L. REV. 1093, 1118-29 (1987).

23 On the importance of generality to the concept of law, see, for example, Plaut $v$. Spendthrift Farm, Inc., 514 U.S. 211, 241-46 (1995) (Breyer, J., concurring); Hurtado v. 
The judicial choice between strong deference and independent review of agency statutory interpretations should therefore turn (at least in part) on a balancing of the advantages of flexible agency interpretation (e.g., expertise) against the rule-of-law advantages that flow from using the courts to narrow agency interpretive discretion. In one sense, this task is impossible because there is no clear calculus for determining the optimal balance between discretion and law. The balance becomes clearer, however, where an agency makes a meaningful commitment to applying its interpretation uniformly across time and parties. Where the executive limits its own discretion with a generally applicable "law" in this way, there is less marginal rule-of-law value to be gained from independent judicial review. ${ }^{24}$ This difference should free courts to indulge in the premise of strong deference that the best way to determine the meaning of an agency's statute is to let the agency figure it out.

But how is an agency to demonstrate the requisite commitment to consistency? Two broad possibilities leap out. First, an agency might use its past consistency to demonstrate present commitment. Where an agency's interpretation has attained "longstanding" status, the agency's history of consistency lessens concerns that it might be manipulating its interpretative discretion for arbitrary, momentary ends, and it enhances the ability of regulated parties to identify controlling norms and to plan accordingly. By providing such rule-of-law benefits through its own self-restraint, an agency tips the balance of interpretive virtue toward application of strong deference by the courts.

Of course, the past cannot justify deference to a new interpretation; the future, however, offers possibilities. The core idea here is that an agency can demonstrate its commitment to a new interpretation by adopting it in a manner that makes it costly to change in the future. This observation leads the commitment theory, like Mead, but for a much more plausible reason, to treat deference as a function of agency procedure because the expected cost to an agency of changing a statutory interpretation will depend in part on what procedure the agency used to create it. The greater the expected cost to

California, 110 U.S. 516, 521 (1884); PAUL W. KAHN, THE REIGN OF LAW 19-23 (1997) (noting attribute of law that it persists over time and that "virtues associated with its rule [include] equality, impartiality, and universality"); Antonin Scalia, The Rule of Law as a Law of Rules, 56 U. CHI. L. REV. 1175, passim (1989) (exploring the "dichotomy between 'general rule of law' and 'personal discretion to do justice'"). See also ROBERT NOzICK, THE NATURE OF RATIONALITY 3-9 (1993) (identifying generality as a feature "necessary for anything to be a law, scientific or moral;" discussing the role of general principles in informing and constraining judicial decision-making).

${ }^{24}$ Cf. Lisa Schultz Bressman, Beyond Accountability: Arbitrariness and Legitimacy in the Administrative State, 78 N.Y.U. L. REV. 461, 529 (2003) (contending that the core concern of administrative law is to guard against arbitrary executive action and that, to that end, it should require "that agencies supply the standards that guide and limit their discretion"). 
change interpretive course, the lesser the danger that an agency will manipulate its interpretation arbitrarily. This observation suggests that among the best candidates for strong deference are interpretations that agencies embed in legislative rules because such rules bind the agencies that produce them until they are properly changed through another legislative rulemaking, ${ }^{25}$ which can be quite onerous. ${ }^{26}$ By contrast, if an agency merely sets forth an interpretation in an opinion letter, internal guidance manual, or the like, then it remains (relatively) free to change interpretive course by any number of cheap means-for example, issuing a new "interpretative" rule. ${ }^{27}$ Such procedures do not evidence as high a level of agency commitment to an interpretation produced through them, which may lead to a fair inference that they should not receive strong deference.

Of course, the Mead framework, too, generally grants strong deference to new interpretations embedded in legislative rules, but not to those included in less formal devices such as opinion letters. ${ }^{28}$ The two theories notably part company, however, in their treatment of interpretations embedded in adjudications. Mead holds that strong deference is broadly applicable to interpretations that agencies produce via formal adjudications that use extensive, judicial-type procedures. ${ }^{29}$ The commitment theory rejects this approach on the ground that adjudication generally leaves agencies too free

25 See I Richard J. Pierce, JR., Administrative Law Treatise, § 6.6, at 354 (4th ed. 2002).

26 The default mode for creating legislative rules under the Administrative Procedure Act (APA) is notice-and-comment. 5 U.S.C. $\$ 553(2000)$ (providing template that enables an agency to promulgate a rule by: (a) publishing notice of its proposal in the Federal Register; (b) accepting and considering comments from interested persons on the proposal; and (c) incorporating in the final rule a "concise general statement of ... basis and purpose"). Although the notice-and-comment process as set forth in the APA sounds straightforward on its face, in practice it can be timeconsuming, expensive, and difficult. See, e.g., Richard J. Pierce, Jr., Seven Ways to Deossify Agency Rulemaking, 47 ADMIN. L. REV. 59, 59-66 (1995) (discussing the "ossification" of agency rulemaking).

${ }^{27}$ See 5 U.S.C. $\$ 553$ (b)(A) (2000) (exempting interpretative rules from notice-andcomment requirements). Of course, one difficulty in discussing the administrative law maze is that attempts to state generalizations about it often require qualification. In this spirit, it bears noting that not all courts take the view that all interpretative rules are cheap to change. Specifically, the D.C. Circuit has held that agencies must use notice-andcomment to change an interpretative rule that construes a legislative rule, but not to change an interpretative rule that construes a statute. Paralyzed Veterans of Am. v. D.C. Arena L.P., 117 F.3d 579, 586 (D.C. Cir. 1997). For a vigorous condemnation of the D.C. Circuit's minority view on this point, see PIERCE, supra note $25, \S 6.4$, at $347-48$.

28 United States v. Mead Corp., 533 U.S. 218, 230-31 (2001).

$29 \mathrm{Id}$. 
to change interpretive course quickly and cheaply. ${ }^{30}$ It does not follow, however, that courts should review all legal interpretations that agencies produce through adjudication de novo. As discussed below, the logic of the commitment theory leaves room for reviving the Hearst doctrine. The Hearst doctrine extends strong deference to administrative resolutions of "mixed" questions of law and fact, which are case-specific determinations of whether a legal term applies to a particular set of facts. ${ }^{31}$ Given their case-specific, fact-sensitive nature, such applications of law to fact do not generalize so easily into abstract legal doctrines, amenable to consistent application. ${ }^{32}$ Courts need not, of course, insist upon agency commitment to consistency where consistency (and thus law) is not practicable.

Stepping back, one overarching virtue of the commitment theory is that it refocuses inquiry with regard to whether strong deference should apply to an agency statutory construction on a sensible question: When can generalist courts add sufficient "rule-of-law" value to the interpretive process to justify applying independent rather than deferential review? The commitment theory offers one plausible, relatively straightforward answer: Courts have the most potential to add rule-of-law value where executive actors fail to constrain their own interpretive discretion in a demonstrable and serious way, and this absence of executive self-restraint justifies the exercise of more searching judicial scrutiny. Surely, this is a more promising line of inquiry than Mead's effort to determine when courts should pretend that Congress cares about agency procedures even though it has not said anything about the matter. ${ }^{33}$

${ }^{30}$ See infra Part III.B.2.d (discussing commitment theory's application to adjudications); see infra note 250 (listing some of the adjudications from 2004 in which the National Labor Relations Board has abandoned a precedent).

31 See infra Part II.A.2 (discussing the Hearst doctrine); Part III.B.2.d (explaining how the commitment theory and the Hearst doctrine might coexist). For a major, recent article contending that Chevron was not in fact a watershed decision and that, to the contrary, the Supreme Court has adhered to Hearst fairly consistently over the decades, see generally John H. Reese, Bursting the Chevron Bubble: Clarifying the Scope of Review in Troubled Times, 73 FoRDHAM L. REV. 1103 (2004).

32 Cf. United States v. McKinney, 919 F.2d 405, 419 (7th Cir. 1990) (Posner, J., concurring) (discussing the futility of appellate attempts to form uniform doctrine out of the resolution of mixed questions).

33 Cf. William R. Andersen, Against Chevron-A Modest Proposal, 56 ADMIN. L. REV. 957, 963 (2004) (noting that "[t]here is nothing per se wrong with legal fictions;" but, in the case of the Chevron doctrine, "the bewildering confusion in the decisions and the commentary suggests that the delegation fiction is not a useful tool"); Ronald $\mathrm{J}$. Krotoszynksi, Jr., Why Deference?: Implied Delegations, Agency Expertise, and the Misplaced Legacy of Skidmore, 54 ADMIN. L. REV. 735, 737 (2002) (contending that deference should be a function of agency expertise rather than fiction). 
Part II of this Article will trace the evolution of the relationship between agency interpretive consistency and judicial deference. Long before Chevron, such consistency was an extremely important factor for deference analysis; the Mead-Chevron framework has created significant confusion concerning this relationship. Part III begins by elaborating on reasons to abandon Mead's mix of fictions and proceduralism. It then provides a theoretical basis for the commitment approach, discussing its roots in the traditional judicial function of policing and limiting official discretion. This part then finishes with an exploration of how the commitment approach might apply to various categories of agency interpretation-for example, longstanding interpretations, interpretations promulgated through notice-and-comment rulemaking, and interpretations announced through adjudications.

\section{AGENCY INTERPRETIVE CONSISTENCY AND JUDICIAL DEFERENCE: FROM VOWELL TO $A D E C$}

For centuries, courts have commonly identified consistency of agency legal interpretation as a prime determinant of judicial deference. But then came 1984's Chevron, which, by glorifying agency interpretive flexibility, suggested that agency consistency should have little bearing on deference. In recent years, the Supreme Court has explained that Chevron deference applies only to favored agency interpretations that carry the "force of law"an elusive concept. Some judicial opinions have indicated that whether an agency interpretation carries the force of law is (at least in part) a function of the agency's consistency; other opinions seem to have ignored this factor. As a result, current doctrine on the significance of agency interpretive consistency to deference is a needlessly confusing mess.

\section{A. Pre-Chevron Links Between Interpretive Consistency and Deference}

\section{Agency Interpretive Uniformity as the Price for Judicial Deference}

During the long pre-Chevron era, courts cited many different factors as justifications for deference in a flexible, pragmatic fashion and were not overly concerned with developing an overarching "theory" on this topic. ${ }^{34}$ The Court's 1944 opinion in Skidmore v. Swift \& Co. exemplifies this flexibility, advising courts that the weight of an agency's construction "in a

34 See Thomas W. Merrill, Judicial Deference to Executive Precedent, 101 YalE L.J. 969, 972-75 (1992) (describing the pre-Chevron, "multiple factors regime" of deference). 
particular case will depend upon the thoroughness evident in its consideration, the validity of its reasoning, its consistency with earlier and later pronouncements, and all those factors which give it power to persuade, if lacking power to control." 35 Beneath this variegated surface, however, were certain recurring dominant themes. One of them was that courts purported to give great weight to longstanding agency statutory constructions.

Chief Justice Marshall's one-paragraph opinion in the 1810 case of United States $v$. Vowell ${ }^{36}$ provides an early illustration of this point. Congress had divided the country into "districts" for customs purposes, each of which could contain several different "port[s] of entry." 37 Vowell turned on whether a cargo of salt had been "imported" into the United States when the ship carrying it arrived in the district of Alexandria or when it later reached the port situated within it. ${ }^{38}$ This point mattered because the ship arrived in the district on December 23,1807; the statutory duty on importing salt lapsed on December 31, 1807; and the ship traveled the last sixteen miles to port on just the day one might expect an intelligent captain to selectJanuary $1,1808 .{ }^{39}$ The collector for Alexandria tried to collect the duty anyway, contending that it had accrued on the ship's entry into the district. ${ }^{40}$

In the first two sentences of its opinion, the Court stated the bald conclusion that it agreed with the defendants-in-error that " $[t]$ he duties [in question] did not accrue in the fiscal sense of the term, until the vessel arrived at the port of entry." 41 It then pointedly added, "[i]f the question had been doubtful, the court would have respected the uniform construction which it is understood has been given by the [T]reasury [D]epartment of the United States upon similar questions." 42 The similar question that the Court had in mind was that the Treasury Department had consistently taken the view that an importer, to avoid a statutory increase in duties with a given effective date, had to get its goods to the port of entry before that datemerely arriving in the collection district would not suffice. ${ }^{43}$ The Court

${ }^{35}$ Skidmore v. Swift \& Co., 323 U.S. 134, 140 (1944).

36 United States v. Vowell, 9 U.S. (5 Cranch) 368 (1810).

$37 \mathrm{Id}$. at 371 .

38 Id. at $368-69$.

${ }^{39} \mathrm{Id}$. at 368 .

${ }^{40} \mathrm{Id}$.

${ }^{41}$ Id. at 372.

42 United States v. Vowell, 9 U.S. (5 Cranch) 368, 372 (1810).

${ }^{43} \mathrm{Id}$. 
concluded that the same "rule of construction" should apply to reductions of duty as to increases. ${ }^{44}$

Although Justice Marshall did not pause to identify it, an obvious equity supported his stance toward uniform executive constructions-the United States should not construe materially identical statutory language differently simply to maximize its income. Given that the United States had chosen a rule of construction that favored its interests as applied to statutes that increase duties, it should apply this same construction to statutes that decrease duties. In modern parlance, one might say that the Court was concerned with preserving uniformity to block an arbitrary result.

Scores of judicial opinions handed down since Vowell have indicated that longstanding consistent agency constructions merit special-even dispositive-weight. ${ }^{45}$ The Court gave an illuminating statement of this rule of construction in its 1929 decision in United States v. Missouri Pacific Railroad Co. in which it observed:

It has been held in many cases that a definitely settled administrative construction is entitled to the highest respect; and, if acted on for a number of years, such construction will not be disturbed except for cogent reasons. But the court is not bound by a construction so established. The rule does

44 Id.

45 For a small sampling of this case law, see, for example, NLRB v. Bell Aerospace Co., 416 U.S. 267, 274-75 (1974) (noting that "a court may accord great weight to the longstanding interpretation placed on a statute by an agency charged with its administration"); Red Lion Broad. Co. v. FCC, 395 U.S. 367, 381 (1969) (stating the "venerable principle that the construction of a statute by those charged with its execution should be followed unless there are compelling indications that it is wrong"); United States v. Chicago, North Shore \& Milwaukee R.R. Co., 288 U.S. 1, 13 (1933) (stating "the rule that settled administrative construction is entitled to great weight and should not be overturned except for cogent reasons"); Louisville \& Nashville R.R. Co. v. United States, 282 U.S. 740, 757 (1931) ("The principal is a familiar one that in the interpretation of a doubtful or ambiguous statute the long[-]continued and uniform practice of the authorities charged with its administration is entitled to great weight and will not be disturbed except for cogent reasons."); Nat'l Lead Co. v. United States, 252 U.S. $140,145-46$ (1920) (" $[I]$ t has been settled law that when uncertainty or ambiguity ... is found in a statute great weight will be given to the contemporaneous construction by department officials . . especially where such construction has been long continued ...."); United States v. Finell, 185 U.S. 236, 244 (1902) (holding that, in case of "doubt," the longstanding interpretation of "the department charged with the execution of the statute should be respected, and not overruled except for cogent reasons"); Edward's Lessee v. Darby, 25 U.S. (12 Wheat) 206, 210 (1827) ("In the construction of a doubtful and ambiguous law, the contemporaneous construction of those who were called upon to act under the law, and were appointed to carry its provisions into effect, is entitled to very great respect."). 
not apply in cases where the construction is not doubtful. And if such interpretation has not been uniform, it is not entitled to such respect or weight, but will be taken into account only to the extent it is supported by valid reasons. ${ }^{46}$

This passage is careful to stress that agency statutory constructions do not "bind" courts as a matter of legal authority; and, in this sense, it is a conceptual world away from the Chevron doctrine. ${ }^{47}$ But on a functional level it seems to instruct courts to extend a similarly strong level of deference to consistent agency constructions - that is, so long as the agency's construction reasonably resolves the meaning of a "doubtful" statute, a court should affirm it unless the court has "cogent reasons" not to do so-in which case the agency's construction was likely not reasonable in the first place. This passage also highlights that the price of inconsistency is a loss of this strong deference-courts are only to affirm non-uniform agency constructions "to the extent [that they are] supported by valid reasons." 48 of course, this remark recalls Skidmore's instruction to courts to affirm those agency interpretations with the "power to persuade." 49

Where courts have explained the basis for deference to longstanding agency constructions, they have often cited three factors. First, they frequently have attributed significance to the fact that an agency construed a statute near the time of its enactment - sometimes on the theory that the agency officials involved might have had special insights concerning the legislative drafting process and intent. ${ }^{50}$ Second, courts have often suggested

46 United States v. Mo. Pac. R.R. Co., 278 U.S. 269, 280 (1929) (emphasis added) (citations omitted).

${ }^{47}$ See Chevron, U.S.A., Inc., v. Natural Res. Def. Council, Inc., 467 U.S. 843, 844 (1984) (describing Chevron deference as a function of legislative delegation of authority to agencies).

${ }^{48}$ Mo. Pac. R.R. Co., 278 U.S. at 280 (1929) (emphasis added) (numerous citations omitted); see also Burnet v. Chicago Portrait Co., 285 U.S. 1, 16 (1932) (observing that inconsistent agency interpretation would "be taken into account only to the extent that it is supported by valid reasons").

${ }^{49}$ See United States v. Mead Corp., 533 U.S. 218, 228 (2001) (quoting Skidmore v. Swift \& Co., 323 U.S. 134, 140 (1944)).

${ }^{50}$ Norwegian Nitrogen Prods. Co. v. United States, 288 U.S. 294, 315 (1933) (observing that "peculiar weight" is owed to "a contemporaneous construction of a statute by the men charged with the responsibility of setting its machinery in motion"); United States v. Moore, 95 U.S. 760, 763 (1877) (observing that the agency officials charged with implementing a statute are "able men" who "[n]ot unfrequently [sic] ... are draftsmen of the laws they are afterwards called upon to interpret"). See also Utah v. Evans, 536 U.S. 452, 472 (2002) (citing the fact that the agency had recommended a statute to Congress as a ground for deferring to the agency's construction of that statute). 
that Congress sometimes ratifies or at least acquiesces to longstanding interpretations; courts are particularly inclined to adopt this justification for deference where, after an agency has construed a statute, Congress reenacts it, or related legislation, without commenting on the agency construction..$^{51}$ Third, courts sometimes justify deference to longstanding executive interpretations on the ground that regulated parties reasonably come to rely on them. ${ }^{52}$ The first two of these factors have a certain make-weight quality - for example, the ratification rationale relies on sometimes dubious assumptions concerning congressional knowledge of agency practices. ${ }^{53}$ The reliance rationale, however, has obvious roots in the rule-of-law idea that regulated parties ought to be able to identify the law and to expect that it will persist for some reasonable period of time.

Certainly, the judicial deference doctrine of the pre-Chevron era did not constitute a coherent body of law, and one must treat generalizations about it with care. ${ }^{54}$ In this vein, one can find cases from this time in which courts arguably minimized or ignored the significance of agency consistency. ${ }^{55}$ Also, courts identified a variety of factors other than consistency as important to deference analysis-for example, whether an agency's analysis seemed thorough. ${ }^{56}$ But, all of this said, a vast amount of case law from that

51 Copper Queen Constr. Mining Co. v. Territorial Bd. of Equalization, 206 U.S. 474,479 (1907) ("[W]hen for a considerable time a statute notoriously has received a construction in practice from those whose duty it is to carry it out, and afterwards is re[Jenacted in the same words, it may be presumed that the construction is satisfactory to the legislature, unless plainly erroneous ...").

52 Udall v: Tallman, 380 U.S. 1, 17 (1965) (quoting United States v. Midwest Oil, 236 U.S. 459, 472-73 (1915)) ("Both officers, law[]makers and citizens naturally adjust themselves to any long-continued action of the Executive Department-on the presumption that unauthorized acts would not have been allowed to be so often repeated as to crystallize into a regular practice. That presumption [is] ... the basis of a wise and quieting rule that in determining the meaning of a statute ... weight shall be given to the usage itself. ...").

53 See PIERCE, supra note $25, \S 6.4$, at 337 (condemning the ratification rationale for deference as "obviously unsound").

54 Robert A. Anthony, Which Agency Interpretations Should Bind Citizens and Courts?, 7 YALE J. ON REG. 1, 6 (1990) ("Judicial attitudes reflected in the opinions range from near-abject acceptance, to a skeptical consideration of agency views, to an ignoring of them altogether.").

55 See, e.g., Bates \& Guild Co. v. Payne, 194 U.S. 106, 111-12 (1904) (Harlan, J., dissenting) (castigating majority for permitting the Postmaster General to abandon a previously uniform construction).

56 See Skidmore v. Swift \& Co., 323 U.S. 134, 140 (1944) (citing thoroughness of agency analysis as one of several factors bearing on agency "persuasiveness"); see also Colin S. Diver, Statutory Interpretation in the Administrative State, 133 U. PA. L. REv. 549, 562 n.95 (1985) (listing ten factors that have been cited by the Supreme Court as 
period supports the intuitively attractive proposition that an agency could earn considerable deference for its construction of a statute that it administers by sticking to it for a long time.

\section{The "Mixed Question" Ground for Deference and its Link to Consistency}

Another extremely important strain of the pre-Chevron case law of deference focused on a fuzzy distinction between "mixed" questions of law and fact on the one hand and "pure" questions of law on the other. 57 Resolution of a mixed question requires a decision-maker to determine whether a given legal term captures some particular state of facts in the world. ${ }^{58} \mathrm{~A}$ pure question of law, by contrast, raises a general issue concerning legal meaning that does not depend on the particular facts of a given case. 59 According to this framework, courts should defer to reasonable agency determinations of mixed questions but should decide pure questions de novo. ${ }^{60}$ Although the connection is not as obvious as in those cases that focused directly on the importance of agency consistency, this pure-mixed dichotomy also suggests a link between deference and a judicial concern to ensure uniformity of law.

The most famous illustration of the pure-mixed dichotomy is NLRB $v$. Hearst Publications, Inc. ${ }^{61}$ This case revolved around whether "newsboys," who sold newspapers for Hearst on account, were independent contractors or were instead "employees" as that term is used in the National Labor Relations Act. ${ }^{62}$ The NLRB concluded that the newsboys were "employees" and thus entitled to the Act's protections. The Supreme Court broke its review of the Board's order into two issues. The first was whether, as Hearst maintained, the statutory term "employee" incorporated common law standards for determining whether an employer-employee relationship exists. ${ }^{63}$ One did not need to know a thing about the details of what newsboys actually did for a living to determine this issue, and its resolution

relevant to deference; notably, five of these ten arguably amount to synonyms for the factor of agency consistency).

57 See, e.g., Anthony, supra note 54, at 8-9 (discussing the distinction between "pure" and "mixed" questions of law in the context of judicial review of agency adjudications).

58 Id. at 9.

59 Id.

60 Id.

61 NLRB v. Hearst Publ'ns, Inc., 322 U.S. 111 (1944).

62 Id. at 113 .

${ }^{63} \mathrm{Id}$. at 120. 
had obvious import for all persons and entities falling within the Board's regulatory grasp. The Court decided this "pure" question of abstract law de novo and ruled that the Act did not adopt common law standards. ${ }^{64}$

The second question was whether, given that common law standards did not control, the newsboys were "employees" within the meaning of the Act-whatever that meaning might be. ${ }^{65}$ To resolve this question, one would need to know a lot about what newsboys did for a living and then apply these facts to a working definition of "employee." 66 Had the Court taken a traditional, common law approach to developing such a gloss, it might have decided this question for itself de novo. Its decision concerning the fate of the newsboys would then have served as a data point for developing a more specific definition of "employee" according to the analogical process of precedent. The newsboys' working conditions would have served as an example of a set of circumstances sufficient (or not) for "employee" status, and later cases would have argued about whether the "newsboy precedent" was on point. But, even granting that this mixed-question holding was amenable to this form of generalization, it obviously lacked the immediate, nationwide punch of the Court's ruling that the Act did not incorporate the common law definition of "employee."

In any event, the Court disclaimed authority to decide this mixed question de novo, holding that "the Board's determination that specified persons are 'employees' under this Act is to be accepted if it has warrant in the record and a reasonable basis in law." 67 As justification for such deference, the Court observed that the task of making such decisions "has been assigned primarily to the agency created by Congress to administer the Act." 68 The Court also explained that deference was appropriate in light of the Board's vast experience in labor relations, which "must be brought frequently to bear on the question who is an employee under the Act" as part of "the usual administrative routine" of the Board." 69

64 See id. at 120-29 (holding, after lengthy independent analysis, that "employee" as used in the Act does not incorporate common law standards).

65 Id. at 130.

${ }^{66} \mathrm{Cf}$. id. at 115-19 (reporting, in considerable detail, the newsboys' working conditions).

${ }^{67}$ NLRB v. Hearst Publ'ns, Inc., 322 U.S. 111, 131 (1944) (quotation marks omitted).

${ }^{68} \mathrm{Id}$. at 130.

${ }^{69} \mathrm{Id}$. 
Of course, as Chevron later demonstrated, the logic of these delegation and expertise rationales can apply to pure questions as easily as mixed. ${ }^{70}$ For example, had the Court determined that the Act was ambiguous with regard to whether its use of the term "employee" incorporated common law standards, then the Court easily could have written an opinion holding that, in light of the Board's expertise, it was plain that Congress wanted the courts to defer to the Board's reasonable resolution of this "pure" issue. Instead, the Hearst Court blocked this path with its bald conclusion that "[u]ndoubtedly[,] questions of statutory interpretation ... are for the courts to resolve." 71

By making this move, the Court reserved for the judiciary the power to determine statutory meaning in those contexts in which it is relatively obvious that an interpretation is likely to have broad significance for later cases. ${ }^{72}$ In other words, where an interpretation amounts to a generalized rule that one can safely expect could apply to many other cases, the courts make those rules. By contrast, at the hazy borderline of fact and law, agencies must make many fine-grained determinations as to how the law should apply to specific facts. Such fact-specific determinations do not generalize so obviously into uniform rules with broad application..$^{73}$ Thus, there was less need for courts to exercise de novo control over such mixed questions to ensure uniformity of law because mixed questions, by their nature, have less potential for broad, uniform application in the first place.

\section{B. Chevron and the Potential Irrelevancy of Agency Interpretive Consistency}

This subpart quickly reviews the familiar facts and deference doctrine of Chevron. It then explores the view-closely associated with Justice Scalia-

70 See infra notes 82-90 and accompanying text (discussing the Court's decision in Chevron to defer to the EPA's statutory construction based on implied-delegation and expertise rationales).

71 Hearst, 322 U.S. at 130-31.

72 Cf. Reese, supra note 31 , at 1108-09 (observing that, pursuant to a Hearst-type approach, courts retain for themselves the power to determine fundamental questions concerning the "macro-meaning" of statutes).

73 Judge Posner made this point with his customary clarity in the course of explaining why appellate courts should review trial court findings of negligence, which call for application of law to fact, for clear error: "[T] he dependence of the determination of negligence on the facts of the particular case, facts that will not recur exactly in any other case, would make quixotic an attempt to bring about uniformity of results by close appellate review." United States v. McKinney, 919 F.2d 405, 419 (7th Cir. 1990) (Posner, J., concurring). 
that agency interpretive consistency has no bearing on the applicability of Chevron deference.

\section{1. (Briefly) Remembering Dear Chevron ${ }^{74}$}

Chevron turned on the construction of the Clean Air Act Amendments of 1977 , which imposed a stringent permit-issuing process to regulate "'new or modified major stationary sources' of air pollution" in states that had not yet succeeded in reducing levels of pollutants to mandated levels. ${ }^{75}$ Much of the punch of this statutory language depended on how one understood the meaning of "stationary source." Suppose, for example, that a utility has three generators-each with one smokestack-at one site. Do the smokestacks count as three "stationary sources" for regulatory purposes, or does the set of three smokestacks count as just one?

In 1980 , the EPA promulgated a rule through notice-and-comment that basically took the former view. ${ }^{76}$ Somewhat ironically, the agency's analysis presupposed a large measure of judicial control over statutory meaning insofar as it relied heavily on two D.C. Circuit opinions that had concluded that this approach to defining "stationary source" best advanced the underlying statutory policy of improving air quality. ${ }^{77}$

${ }^{74}$ Many others have remembered Chevron before-the law review literature discussing its doctrine (and the attitudes toward separation of powers and the modern administrative state that underlie it) is beyond huge. For a representative sampling from leading articles on this topic, see, for example, Cass R. Sunstein, Chevron Step-Zero, 92 VA. L. REV. (forthcoming Apr. 2006), available at http://ssm.com/abstract id=739129; Reese, supra note 31; Elizabeth Garrett, Legislating Chevron, $101 \mathrm{MICH}$. L. REV. 2637 (2003); David J. Barron \& Elena Kagan, Chevron's Nondelegation Doctrine, 2001 SUP. CT. REV. 201; Merrill \& Hickman, supra note 13; John F. Duffy, Administrative Common Law in Judicial Review, 77 TEX. L. REV. 113 (1998); Ronald M. Levin, The Anatomy of Chevron: Step Two Reconsidered, 72 CHI.-KENT L. REV. 1253 (1997); Mark Seidenfeld, A Syncopated Chevron: Emphasizing Reasoned Decisionmaking in Reviewing Agency Interpretations of Statutes, 73 TEX. L. REV. 83 (1994); Thomas W. Merrill, Judicial Deference to Executive Precedent, 101 YALE L.J. 969 (1992); Anthony, supra note 54; Cass R. Sunstein, Law and Administration After Chevron, 90 CoLUM. L. REV. 2071 (1990); Cynthia R. Farina, Statutory Interpretation and the Balance of Power in the Administrative State, 89 CoLUM. L. REV. 452 (1989). (1984).

75 Chevron, U.S.A., Inc. v. Natural Res. Def. Council, Inc., 467 U.S. 837, 840

76 Id. at 857 .

77 Id. (citing the EPA's discussion of the meaning of "source" at 45 Fed. Reg. 52,697 (Aug. 7, 1980), which relied on Alabama Power Co. v. Costle, 636 F.2d 323 (D.C. Cir. 1979), and ASARCO, Inc. v. EPA, 578 F.2d 319 (D.C. Cir. 1978)). 
A year later, in 1981, with a new administration in power, the EPA saw matters differently and promulgated a new rule, also through notice-andcomment, that took the latter view-commonly known as the "bubble concept" approach. ${ }^{78}$ From the regulated entities' perspective, the great advantage of the bubble-concept approach was that it only required a company to acquire a new permit when its modifications would cause the total amount of emissions escaping from a hypothetical bubble encasing its entire plant to increase. A company could, without a permit, make modifications that would increase emissions escaping from one smokestack within a plant so long as it found offsetting ways to decrease emissions escaping from other smokestacks - thereby ensuring that the total amount escaping from the regulatory bubble did not increase. ${ }^{79}$

Environmental groups challenged the new rule in the D.C. Circuit Court of Appeals, which acknowledged that the statutory phrase "stationary source" was ambiguous. ${ }^{80}$ It nonetheless rejected the EPA's bubble-concept construction of this phrase on the ground that it conflicted with the statutory policy of air quality improvement that the court had identified in its own earlier interpretive efforts. ${ }^{81}$

The Supreme Court reversed, scolding the D.C. Circuit for relying on its own statutory judgment rather than extending strong deference to the agency. ${ }^{82}$ In defense of the lower court, it should be noted that certain traditional grounds for deference were plainly inapplicable in this case. The principle that longstanding agency interpretations warrant deference could not help the agency because its new rule amounted to a flip-flop. Also, the Hearst mixed-question approach did not support deference because the issue as to whether the statutory phrase "stationary source" had room enough to admit the bubble concept was about as "pure" a question of law as one would be likely to find.

With these more limited rationales for deference blocked, the Court responded with the deference blunderbuss now affectionately known as the Chevron two-step:

When a court reviews an agency's construction of the statute which it administers, it is confronted with two questions. First [(step one)], always, is the question whether Congress has directly spoken to the precise question

78 Chevron, 467 U.S. at $857-58$.

${ }^{79} \mathrm{Id}$. at 840 .

80 Natural Res. Def. Council, Inc. v. Gorsuch, 685 F.2d 718, 723 (D.C. Cir. 1982), rev'd sub nom. Chevron, U.S.A., Inc. v. Natural Res. Def. Council, Inc., 467 U.S. 837 (1984).

${ }^{81}$ Gorsuch, 685 F.2d at 725-28.

82 Chevron, 467 U.S. at 842. 
at issue. If the intent of Congress is clear, that is the end of the matter; for the court, as well as the agency, must give effect to the unambiguously expressed intent of Congress. If, however, the court determines Congress has not directly addressed the precise question at issue, the court does not simply impose its own construction on the statute, as would be necessary in the absence of an administrative interpretation. Rather [(step two)], if the statute is silent or ambiguous with respect to the specific issue, the question for the court is whether the agency's answer is based on a permissible construction of the statute. ${ }^{83}$

The Court cited two very different rationales for this approach. First, it gave a delegation explanation-that Congress wants agencies to exercise primary control over interpretation of agency organic statutes, and courts must obey this legislative intent. ${ }^{84}$ One problem with this notion is that although Congress does, on occasion, expressly grant legislative authority to an agency to refine the meaning of the terms of its own statute, ${ }^{85}$ most of the time Congress says nothing on the matter. ${ }^{86}$ The Court dodged this problem by indicating that the very existence of ambiguity in an agency's organic statute reveals an "implicit" congressional intent to delegate interpretive authority to the agency. ${ }^{87}$ As many have noted, this theory of "implicit delegation" rests on a transparent fiction. ${ }^{88}$

The Court's second rationale for strong deference explained that agencies are, generally speaking, better interpreters of their own organic statutes than courts- thus justifying the first fiction that Congress wants

${ }^{83} \mathrm{Id}$. at $842-43$ (footnotes omitted).

${ }^{84} \mathrm{Id}$. at 843-44. One of the ironies of Chevron's reliance on an implicit delegation story is that the Court did not consider the APA's express directions from Congress to the courts regarding standards of review, which instruct them to "decide all relevant questions of law." 5 U.S.C. $\$ 706$ (2000). One can easily imagine courts construing this language to require de novo review. See, e.g., United States v. Mead Corp., 533 U.S. 218, 241 n.2 (2001) (Scalia, J., dissenting) (noting that Chevron ignored the APA); Duffy, supra note 74, at 193-95 (contending that legislative history of $\S 706$ indicates that Congress expected courts to resolve issues of statutory meaning independently).

85 See, e.g., 29 U.S.C. $\$ 213($ a)(15) (2000) (authorizing Secretary of Labor to promulgate legislative regulations to define "companionship services" for purpose of Fair Labor Standards Act wage requirements).

${ }^{86}$ Barron \& Kagan, supra note 74, at 212 ("Although Congress can control applications of Chevron, it almost never does so, expressly or otherwise; most notably, in enacting a standard delegation to an agency to make substantive law, Congress says nothing about the standard of judicial review.").

${ }^{87}$ Chevron, U.S.A., Inc. v. Natural Res. Def. Council, Inc., 467 U.S. 837, 844 (1984).

88 See, e.g., Andersen, supra note 33, at 963; Krotoszynski, supra note 33, at 737. 
agencies to wield primary interpretive authority even where it does not say so. The resolution of true ambiguity in an agency's organic statute requires policymaking. ${ }^{89}$ Agencies, not courts, should make such choices because: (a) agencies generally possess greater technocratic expertise than courts; and (b) as denizens of the executive branch, agencies are more politically accountable than life-tenured judges. ${ }^{90}$ In short, agencies have both more interpretive ability and legitimacy than do courts.

\section{Agency Interpretive Consistency as Post-Chevron Irrelevancy}

In Chevron, the Court responded to petitioners' charge that the EPA's flip-flopping should deprive it of deference by praising agency interpretive flexibility, observing that "[a]n initial agency interpretation is not instantly carved in stone. On the contrary, the agency, to engage in informed rulemaking, must consider varying interpretations and the wisdom of its policy on a continuing basis."9l This praise of interpretive flexibility suggested that the age and consistency of an agency's interpretation should not have much bearing on deference analysis.

Justice Scalia - that most aggressive and powerful fan of the Chevron doctrine-penned a strong confirmation of this view for a unanimous Court in Smiley v. Citibank (South Dakota), N.A., ${ }^{92}$ which addressed a California credit cardholder's claim that the late-fees charged by the national bank that had issued her card violated California law. ${ }^{93}$ Under the National Bank Act of 1864 , a national bank may charge "interest at the rate allowed by the laws of the State ... where the bank is located." 94 If the statutory term "interest" included late fees, then the cardholder's claim was doomed as, suffice to say, the card-issuing bank had picked South Dakota as its home for a reason. ${ }^{95}$

While this case was pending, the Comptroller of the Currency issued a notice-and-comment rule that included an interpretation of "interest" broad enough to grab late fees. ${ }^{96}$ The card-holding claimant argued that this construction did not merit strong deference given that the Comptroller had issued it over 100 years after enactment of the statutory provision at issue.

89 Chevron, 467 U.S. at $864-66$.

$90 \mathrm{Id}$.

91 Id. at 863-64.

92 Smiley v. Citibank, N.A., 517 U.S. 735 (1996).

93 Id. at $737-38$.

94 Id. at 737 (material omitted in the original) (quoting National Bank Act of 1864 , $\S 30,12$ U.S.C. $\$ 85(2000))$.

95 See id. at 737-38.

96 Id. at 739-40 (quoting 61 Fed. Reg. 4869 (Feb. 9, 1996)). 
The Court's response to this point minimized the importance of an interpretation's age:

The 100-year delay makes no difference. To be sure, agency interpretations that are of long standing come before us with a certain credential of reasonableness, since it is rare that error would long persist. But neither antiquity nor contemporaneity with the statute is a condition of validity. We accord deference to agencies under Chevron, not because of a presumption that they drafted the provisions in question, or were present at the hearings, or spoke to the principal sponsors; but rather because of a presumption that Congress, when it left ambiguity in a statute meant for implementation by an agency, understood that the ambiguity would be resolved, first and foremost, by the agency, and desired the agency (rather than the courts) to possess whatever degree of discretion the ambiguity allows. ${ }^{97}$

The cardholder had also argued that the Comptroller's interpretation of "interest" as capturing late fees was not entitled to strong deference because it was inconsistent with earlier interpretations of the term adopted by the same office. ${ }^{98}$ The Court rejected the factual premise of this argument, concluding that nothing "which can accurately be described as a change of official agency position has occurred here." 99 Even if the cardholder's characterization of the Comptroller's interpretations had been accurate, however, it was largely irrelevant to the analysis because, as Justice Scalia explained:

[T] he mere fact that an agency interpretation contradicts a prior agency position is not fatal. Sudden and unexplained change, or change that does not take account of legitimate reliance on prior interpretation, may be "arbitrary, capricious [or] an abuse of discretion," 5 U.S.C. $\S 706(2)(A)$. But if these pitfalls are avoided, change is not invalidating, since the whole point of Chevron is to leave the discretion provided by the ambiguities of a statute with the implementing agency. ${ }^{100}$

${ }^{97}$ Id. at $740-41$.

98 Smiley v. Citibank, N.A., 517 U.S. 735, 740-41 (1996).

${ }^{99} \mathrm{Id}$.

100 Id. (citations omitted). See also Nat'l Cable \& Telecomms. Ass'n v. Brand X Internet Servs., 125 S. Ct. 2688, 2699 (2005) ("Agency inconsistency is not a basis for declining to analyze the agency's interpretation under the Chevron framework."); FDA v. Brown \& Williamson Tobacco Corp., 529 U.S. 120, 186 (2000) (Breyer, J., dissenting) (observing that the FDA's change in position regarding whether tobacco fell within its statutory authority to regulate "does not make a significant legal difference"); Rust $\mathbf{v}$. Sullivan, 500 U.S. 173, 186-87 (1991) (adverting to the Chevron principle that initial agency interpretations are not "instantly carved in stone"; approving change of statutory 
Cases like Smiley seemed to confirm that Chevron deference should apply to an agency's interpretation regardless of whether that interpretation is old, new, or marks a change in interpretive course. Consistency could not earn strong deference for an agency because Smiley presupposes the particular view of its author Justice Scalia that strong deference applies to all authoritative constructions by an agency of a statute it administers in any event. ${ }^{101}$ Nor could inconsistency cause a loss of strong deference because, under Chevron, agencies are supposed to be able to change their interpretations as new circumstances warrant.

\section{A "Force of Law" Limitation for Strong Deference}

Courts and scholars have struggled for the last twenty years to devise a clear framework for determining which types of agency interpretation should receive Chevron's strong deference. ${ }^{102}$ In Chevron itself, the Court arguably regarded the presence of ambiguous language in an agency's organic statute as a definitive signal that Congress wanted the agency administering the statute, not the courts, to take primary charge of interpretation. ${ }^{103}$ The interpretation at issue in Chevron, however, had been vetted by notice-andcomment, which left open the possibility that strong deference should apply only to interpretations produced via favored, relatively extensive, procedures. ${ }^{104}$ Courts disagreed on this point: a few limited strong deference to rulemaking; many extended it to the interpretive products of legislative rulemaking or formal adjudication; and still others freely extended Chevron to interpretations contained in less formal formats such as interpretive rules, manuals, opinion letters, and the like. ${ }^{105}$

construction as "the Secretary amply justified his change of interpretation with a 'reasoned analysis"').

101 Cf. United States v. Mead Corp., 533 U.S. 218, 241 (2001) (Scalia, J., dissenting) (contending that, under the Chevron doctrine, "all authoritative agency interpretations of statutes they are charged with administering deserve deference").

102 For the two leading articles on this topic, see Merrill \& Hickman, supra note 13, at 848-52 (identifying fourteen then-unresolved questions concerning the scope of Chevron's applicability); Anthony, supra note 54, passim (developing influential argument that an interpretation's eligibility for Chevron deference should depend on the format an agency used to create it).

103 See generally Chevron, U.S.A., Inc. v. Natural Res. Def. Council, Inc., 467 U.S. $837,840-45$ (1984) (treating statutory ambiguity as an implicit delegation of interpretive authority to agency).

104 See id. at 858-59.

105 See, e.g., PIERCE, supra note $25, \S 3.5$, at 152 (collecting cases demonstrating that prior to 2000 , courts were in "widespread disagreement" concerning the kinds of formats entitled to Chevron deference). 
Since 2000, the Supreme Court has made two especially noteworthy efforts to resolve this problem of determining Chevron's reach. The first of these was Christensen v. Harris County, in which a five-justice majority expressed the view that only those agency statutory interpretations that carry the "force of law" merit strong deference. ${ }^{106}$ A year later, in United States $v$. Mead Corp., an eight-justice majority attempted to clarify this "force of law" line in the sand. ${ }^{107}$ In neither case, however, did the Court provide a clear definition of the meaning of "force of law." Worse, Mead is downright incoherent on this point, as it both supports and contradicts the thesis that, to earn strong deference for an interpretation, an agency must commit to its general application. ${ }^{108}$

\section{Adopting the "Force of Law" Line}

The Chevron issue in Christensen was how much weight should be given to an agency opinion letter. ${ }^{109}$ The Fair Labor Standards Act (FLSA) permits state political subdivisions to compensate employees for overtime with "comp time" rather than with extra pay. ${ }^{110}$ This power is subject, however, to the qualification that if an employee does not use up his or her comp time within a given period, he or she can claim the cash instead. ${ }^{111}$ To avoid this prospect, Harris County wanted to force its employees to take time off. It inquired of the Department of Labor whether this course of action was legal. The Acting Administrator of the Wage and Hour Division responded in an opinion letter that the FLSA only permitted an employer to schedule the unwilling use of comp time where such action had been specifically authorized by a preexisting agreement with its employees. ${ }^{112}$ Harris County had no such agreement with its deputy sheriffs, but scheduled their comp time anyway. Preferring cash to leisure, the deputy sheriffs sued.

In an opinion authored by Justice Thomas, the Court sided with Harris County, rejecting the agency's reading of the FLSA as unpersuasive. ${ }^{113}$ To

106 Christensen v. Harris County, 529 U.S. 576, 587 (2000).

107 United States v. Mead Corp, 533 U.S. 218, 226-27 (2001).

108 Cf. Ronald M. Levin, Mead and the Prospective Exercise of Discretion, 54 ADMIN. L. REV. 771, 799 (2002) (noting that "Mead seems likely to contribute to confusion ... because the Court appeared to lack a coherent notion of what it means to say that an action has the 'force of law'").

${ }^{109}$ Christensen, 529 U.S. at 587.

$110 \mathrm{Id}$. at 579 (citing 29 U.S.C. $\$ 207(\mathrm{o})(1)(2000)$ ).

111 Id. at 580 (citing 29 U.S.C. $\S 207$ (o)(3)(A) (2000)).

112 Id. at 581 (quoting Opinion Letter of the Acting Wage Administrator, [2 WagesHours] Lab. L. Rep. (CCH) ๆ 31,040 (Sept. 14, 1992)).

113 Christensen v. Harris County, 529 U.S. 576, 585 (2000). 
try to avoid this result, the deputy sheriffs had argued that the Acting Administrator's opinion letter was entitled to Chevron deference. The Court rejected this contention:

[W] confront an interpretation contained in an opinion letter, not one arrived at after, for example, a formal adjudication or notice-and-comment rulemaking. Interpretations such as those in opinion letters-like interpretations contained in policy statements, agency manuals, and enforcement guidelines, all of which lack the force of law-do not warrant Chevron-style deference. Instead, interpretations contained in formats such as opinion letters are "entitled to respect" under our decision in Skidmore v. Swift \& Co., but only to the extent that those interpretations have the "power to persuade." As explained above, we find unpersuasive the agency's interpretation of the statute at issue in this case. ${ }^{114}$

Three justices expressed reservations about the "force of law" line that the majority opinion drew between the domains of Chevron's strong and Skidmore's weak deference. Justice Scalia, as one might expect, contended that Chevron established that strong deference should apply to all "authoritative" agency interpretations without regard to their procedural history. ${ }^{115} \mathrm{He}$ condemned Skidmore deference as "an anachronism, dating from an era in which we declined to give agency interpretations ... authoritative effect." 116

Justice Breyer, in a dissent joined by Justice Ginsburg, took a more nuanced view. Although he conceded that Justice Scalia "may well be right" that Chevron deference applied to the agency opinion letter, he rejected the characterization of Skidmore as anachronistic, noting that it could apply in those circumstances where there were grounds to doubt that "Congress actually intended to delegate interpretive authority to the agency." $117 \mathrm{He}$ did not need to reach the issue of whether one form of deference applied to the exclusion of the other because, in his view, the agency's position was "eminently reasonable, hence persuasive, whether one views that decision through Chevron's lens, through Skidmore's, or through both."118 In light of the sharp distinction the Court would draw between Chevron and Skidmore deference just a year later in Mead, ${ }^{119}$ it bears noting that Justice Breyer's

114 Id. at 586-87 (citations omitted).

115 Id. at 590 (Scalia, J., concurring in part and concurring in the judgment).

116 Id. at 589 (citation omitted).

117 Id. at 596-97 (Breyer, J., dissenting).

118 Id. at 597 (Breyer, J., dissenting).

119 See United States v. Mead Corp., 533 U.S. 218, 234-35 (2001) (holding that Skidmore, rather than Chevron, deference should apply to Customs ruling letter). 
dissent in Christensen seemed to presuppose that both Chevron and Skidmore call for a similar form of rationality review. ${ }^{120}$

Of greatest import for the present purpose, none of the Christensen opinions explained what it means for an agency interpretation to have the "force of law." Given that this concept has been the subject of significant confusion in administrative law, there was little reason to expect that Christensen, by itself, would settle the problem of determining Chevron's precise reach.

\section{The "Force Of Law" Gets Downright Confusing}

In 2001's United States v. Mead Corp., an eight-justice majority of the Court (with Justice Scalia the outraged dissenter) made a grand, selfconscious effort to clarify the force-of-law limits on Chevron deference set forth in the fractured Christensen opinion the year before. ${ }^{121}$ This case turned on whether loose-leaf, three-ring day-planners imported by Mead Corp. (Mead) were "bound" "diaries" within the meaning of the Harmonized Tariff Schedule of the United States. ${ }^{122}$ Customs had for some time taken the view that these day-planners did not fall into this category. In 1993, the agency

${ }^{120}$ Cf. Jim Rossi, Respecting Deference: Conceptualizing Skidmore Within the Architecture of Chevron, 42 WM. \& MARY L. REV. 1105, 1137-39 (2001) (explaining that, for Justice Breyer, Skidmore review fits within the "architecture" of Chevron deference).

121 Mead, 533 U.S. at 218. Mead quickly generated a considerable amount of scholarly commentary-much of it negative. See, e.g., Bressman, supra note 17, passim (providing extensive review of confused lower-court applications of Mead); Adrian Vermeule, Introduction: Mead in the Trenches, 71 GEO. WASH. L. REV. 347 (2003) (condemning Mead's effort to develop a "fine-grained" approach to deference); Michael P. Healy, Spurious Interpretation Redux: Mead and the Shrinking Domain of Statutory Ambiguity, 54 ADMIN. L. REV. 673, 674 (2002) (contending that "Mead's interpretive approach ... load[s] the interpretive dice... and thereby arrogates to the judiciary lawmaking power better exercised by the legislature or the agency"); William S. Jordan, III, Judicial Review of Informal Statutory Interpretations: The Answer Is Chevron Step Two, Not Christensen or Mead, 54 ADMIN. L. REV. 719, 725 (2002) (condemning the "Mead mess"; suggesting that the Court's effort to improve judicial review would have been better served by strengthening Chevron step-two rationality review); Krotoszynski, supra note 33, at 737 (contending that the deference inquiry should focus on agency expertise rather than on a search for a fictional implied delegation); Levin, supra note 108, at 773 (suggesting that, contra Mead, Chevron's applicability should depend solely on whether the agency in question possesses delegated authority to act with the force of law); Thomas W. Merrill, The Mead Doctrine: Rules and Standards, Meta-Rules and Meta-Standards, 54 ADMIN. L. REV. 807, 809 (2002) (contending that the Court should have adopted a clear "meta-rule" for determining when Chevron applies).

122 Mead, 533 U.S. at 225. 
changed course and issued a ruling letter declaring that they did, which meant that they were newly subject to a four percent tariff. ${ }^{123}$ Mead appealed this ruling through Customs' internal review process, the Court of International Trade, and the Federal Circuit. ${ }^{124}$ The Federal Circuit rejected Customs' ruling on the grounds that the day-planners were not "diaries" and, for that matter, were not "bound," either. ${ }^{125}$ In the course of this analysis, the circuit court expressly refused to give any deference to Customs' interpretation of these terms. ${ }^{126}$

The Supreme Court seized on the Federal Circuit's refusal to extend deference as a chance to elaborate on the rule of Christensen. ${ }^{127}$ It started its analysis by offering the following broad observation on the reach of Chevron:

We hold that administrative implementation of a particular statutory provision qualifies for Chevron deference when it appears [(1)] that Congress delegated authority to the agency generally to make rules carrying the force of law, and [(2)] that the agency interpretation claiming deference was promulgated in the exercise of that authority. 128

This framework raises the threshold problem of determining where Congress has intended to grant an agency the power to make rules with the "force of law." The Court observed that such a delegation "may be shown in a variety of ways, as by an agency's power to engage in adjudication or notice-and-comment rulemaking." 129 It further explained that a link existed between Chevron's applicability and extensive procedure because it was fair to assume that Congress would expect interpretations adopted after relatively

$123 \mathrm{Id}$. at $224-25$.

124 Id. at 225.

125 Mead Corp. v. United States, 185 F.3d 1304, 1308-1 1 (1999).

126 Id. at 1307.

127 See United States v. Mead Corp., 533 U.S. 218, 226 (2001).

${ }^{128}$ Id. at 226-27 (emphasis added).

${ }^{129}$ Id. at 227 . It bears noting that the Court could not have literally meant that the power to "adjudicate," in itself, signals a silent delegation from Congress of the power to imbue interpretations with the force of law. As defined by the APA, "adjudication" is the process for formulating a final disposition in any matter other than rulemaking. 5 U.S.C. $\S 551(6)-(7)(2000)$. What the Court apparently meant was that Congress can signal its delegation of power to act with the "force of law" by requiring an agency to use relatively extensive, "formal" procedures for adjudication. See Mead, 533 U.S. at 230 (linking delegation to use of extensive procedure). 
formal procedures to enjoy the force of law. 130 This fine-grained, fictional legislative intent had the great advantage of justifying most of the Court's past applications of Chevron, which it noted had, in an "overwhelming" majority of cases, "reviewed the fruits of notice-and-comment rulemaking or formal adjudication."131 The Court could not, however, make such procedures a necessary condition for Chevron deference without disavowing precedents in which it had applied strong deference in their absence. ${ }^{132}$ It therefore conceded that Congress could signal the needed "force of law" delegation by "other" unspecified means. ${ }^{133}$ In short, the Court told a juryrigged implicit-delegation story that had the convenient quality of legitimating the Court's own past practices.

Looking past Mead's fuzzy edges, the case did send a clear signal that the Court expects that interpretations produced through either notice-andcomment or formal adjudication will typically enjoy the "force of law." This expectation makes perfect sense for interpretations produced through noticeand-comment, which the APA specifies as the default procedure for producing legislative rules. ${ }^{134}$ Subject to the caveat that a legislative rule may be challenged in court for arbitrariness, such rules bind agencies, the public, and the courts until they are properly changed either by a later legislative rule or by statute. 135

There are several reasons why it must have been tempting for the Court to characterize agency interpretations produced via formal adjudication as carrying the "force of law." For one thing, as just noted, this characterization had the advantage of telling a story that justified the Court's earlier opinions in which it had extended strong deference to such interpretations. Also, a good deal of influential scholarship on the subject had for some time contended -albeit with more nuance than Mead - that at least some interpretations produced via formal adjudication should net strong deference

${ }^{130}$ See Mead, 533 U.S. at 230 ("It is fair to assume generally that Congress contemplates administrative action with the effect of law when it provides for a relatively formal administrative procedure tending to foster the faimess and deliberation that should underlie a pronouncement of such force.") (citation omitted).

${ }^{131} \mathrm{Id}$. (footnotes and citations omitted).

132 See id. at 231 (citing NationsBank, N.A. v. Variable Annuity Life Ins. Co., 513 U.S. 251, 256-57 (1995) (granting Chevron deference to a statutory interpretation that the Senior Deputy Comptroller of the Currency had included in a letter to a private party because the "Comptroller... is charged with the enforcement of banking laws to an extent that warrants [deference] with respect to his deliberative conclusions as to the meaning of these laws")).

133 United States v. Mead Corp., 533 U.S. 218, 227 (2001).

1345 U.S.C. $\$ 553$ (2000).

135 PIERCE, supra note $25, \S 6.6$, at 354 . 
because they possess the "force of law."136 In addition, we commonly characterize the courts' judicial interpretations as case "law"; by analogy, it seems plausible that agency interpretations produced through judicial-type procedures might also merit that designation.

It puts a severe strain, however, on certain earlier administrative-law treatments of the "force of law" to characterize agency adjudicative interpretations as possessing this quality, as review of the plurality opinion in the administrative law chestnut NLRB v. Wyman-Gordon Co. highlights. ${ }^{137}$ This case involved a challenge to the Board's order to the respondent company to supply union organizers with a list of employees eligible to vote for representation. The Board's order relied on a so-called "rule" requiring the provision of such lists that the Board had purported to create but had not applied in an earlier formal adjudication, Excelsior Underwear, Inc. ${ }^{138}$ The plurality opinion rejected the proposition that the Excelsior "rule" could function like a valid legislative rule on the ground that adjudications may specify agency policies or precedents, but they do not create binding law in the same manner as a bona fide rulemaking can:

Adjudicated cases may and do, of course, serve as vehicles for the formulation of agency policies, which are applied and announced therein. They generally provide a guide to action that the agency may be expected to take in future cases. Subject to the qualified role of stare decisis in the administrative process, they may serve as precedents. But this is far from saying, as the Solicitor General suggests, that commands, decisions, or policies announced in adjudication are "rules" in the sense that they must, without more, be obeyed by the affected public. ${ }^{139}$

Thus, an "interpretation" of an agency organic statute adopted through formal adjudication acquires whatever prospective force it might possess not because it writes a new "law" that binds regulated parties, regulators, and

136 See Anthony, supra note 54, at 39, 46-50 (contending that, where Congress delegates policymaking power to an agency, that grant carries with it the power to resolve mixed questions of law and fact with the "force of law" through adjudication); Merrill \& Hickman, supra note 13, at 881-82 (contending that "[a]gency action has the force of law when, of its own force and effect, it commands certain behavior and subjects parties to penalties or sanctions if they violate this command," and that, by this criterion, an agency directive issued through an adjudication carries the force of law if its violation could "result in the immediate imposition of sanctions unless the rule or order is set aside on review or stayed pending review").

${ }^{137}$ NLRB v. Wyman-Gordon Co., 394 U.S. 759 (1969) (Fortas, J.) (plurality opinion).

${ }^{138}$ Excelsior Underwear, Inc., 156 N.L.R.B. 1236 (1966).

139 Wyman-Gordon Co., 394 U.S. at 765-66 (citations omitted) (emphasis omitted). 
courts, but rather because a sensible regulated party should expect that the agency will likely stick to this interpretation in later cases.

A reader of a legal-realist bent might at this point object that to characterize legislative rules as bona fide "law" and adjudicatory interpretations as mere "precedent" is to indulge in a silly formalism. Again, just as one can reasonably refer to judicial precedents as "law," so agency precedents, too, can merit that designation. This hypothetical objection misses a crucial distinction between judicial and administrative precedent. The law-like quality of case-law flows from precedential force; one should expect an interpretation of law adopted in a given case to function as law in later cases precisely because stare decisis requires courts to defer to past judicial opinions. In many contexts, these bonds of judicial stare decisis are quite strong-for example, lower courts must strictly obey the precedents of their superiors; ${ }^{140}$ also, the various circuit courts in the federal system generally treat their own (published) precedents as strictly binding. ${ }^{141} \mathrm{By}$ contrast, an agency is free to depart from an interpretation or policy it adopts through adjudication provided that its explanation for its departure can survive judicial review for arbitrariness. ${ }^{142}$ Because agency "precedents" do not bind later agency decision-making in any serious way, they do not possess the same potential as judicial precedents to create generally applicable and binding law. ${ }^{143}$

It nonetheless remains the case that Mead indicated that Chevron deference should generally apply to interpretations that agencies produce through formal adjudication. It would seem to follow that, regardless of the views expressed in Wyman-Gordon, whatever "force" interpretations produced through formal adjudication may possess must be sufficient to amount to the "force of law" in Mead's sense of the phrase. Although such interpretations do not bind agencies themselves in later cases, they may of course bind the regulated party on the receiving end of an administrative

140 See Evan H. Carminker, Why Must Inferior Courts Obey Superior Court Precedents?, 46 STAN. L. REV. 817, 820 (1994) (describing the strictly binding vertical effect of precedent as an "axiom of adjudication").

141 See Melissa M. Serfass \& Jessie L. Cranford, Federal and State Court Rules Governing Publication and Citation of Opinions, 3 J. APP. PRAC. \& PROCESS 251, 253-57 (2001) (collecting circuit court rules on intra-circuit precedential force of published panel opinions).

142 See supra note 100 and accompanying text (discussing duty of agencies to explain departures from their own precedents).

143 But see Merrill, The Mead Doctrine, supra note 121, at 816-17, 827 (agreeing that to carry the "force of law," a decision must have binding effect beyond the parties to the ruling, but also suggesting that the precedential force of an administrative adjudication can suffice for the creation of this binding effect). 
order in a given case. ${ }^{144}$ They also may "bind" the courts in the questionbegging sense that, if the courts apply Chevron deference to such an interpretation, then they should affirm that interpretation provided that it is minimally rational. At this stage, it would appear that these qualities suffice for Mead's "force of law."

Mead's analysis of whether strong deference should apply to the Customs ruling letter at issue in that case, however, belied its own apparent understanding of "force of law." Although this ruling letter was a product of informal adjudication, it enjoyed the "force of law" in the limited sense that it bound Mead itself. ${ }^{145}$ The Court nonetheless cited a laundry list of factors as evidence that the letter lacked such force, including: (a) Customs regards its ruling letters "as conclusive only as between itself and the importer to whom it was issued"; (b) ruling letters are only controlling until the agency gives "advance notice of an intended change"; (c) Customs affirmatively warns third parties against relying on letters issued to others; and (d) fortysix regional Customs offices issue 10,000 to 15,000 ruling letters per year with little or no procedure. ${ }^{146}$ In light of these observations, the Court concluded that the ruling letters did not "bespeak the legislative type of activity that would naturally bind more than the parties to the ruling, once the goods classified are admitted into this country."147 Moreover, any limited value that the ruling letters might possess as precedents was irrelevant because "precedential value alone does not add up to Chevron entitlement."148 Boiling this down, the Customs ruling letter issued to Mead lacked the "force of law" - even though it bound Mead itself - because it left Customs free to change course whenever it pleased in any minimally rational way. To say the least, this letter did not mark a substantial agency commitment to uniform interpretation.

In sum, the great internal contradiction lying in the heart of Mead is that, by indicating that interpretations produced through formal adjudication generally warrant strong deference, it suggested that an agency interpretation

144 Cf. Levin, supra note 108, at 799-800 (observing that "[f]ormal adjudications (and for that matter informal adjudications) are not binding on third parties, but they do have the 'force of law,' because they determine the legal rights of the parties"); Merrill \& Hickman, supra note 13, at 881-82 (contending that agency adjudicative orders that have the power to bind parties have the "force of law" in Chevron's sense).

145 Cf. Barron \& Kagan, supra note 74, at 217 (observing that, if "force of law" is the correct criterion for strong deference, then the Customs ruling letter arguably had such force given that the letter was binding on Mead itself).

146 United States v. Mead Corp., 533 U.S. 218, 232-33 (2001) (citations omitted).

147 Id. at 232 (emphasis added).

${ }^{148}$ Id. (citing Peter Strauss, The Rulemaking Continuum, 41 DUKE L.J. 1463, 1472$73(1992))$. 
need not significantly constrain an agency's later interpretive discretion to enjoy the force of law; Mead's actual grounds for denying strong deference to the Customs ruling letter suggest the opposite.

\section{The Post-Mead Significance of Commitment to Future Consistency}

The "down and dirty" way to read Mead is that it counsels that strong deference applies to interpretive products of notice-and-comment rulemaking and formal adjudication. One can see echoes of Mead's mixed messages on the "force of law" in two interesting categories of recent circuit court cases in which this generalization breaks down: (a) cases denying strong deference to interpretations produced through formal adjudication; and (b) cases extending strong deference to interpretations that were not produced through either of the "safe harbor" procedures. In the first of these categories, courts have treated agency commitment to consistency as a necessary condition for strong deference; in the second, they have treated it as a sufficient condition.

The Ninth Circuit's decision in Hernandez $v$. Ashcroft ${ }^{149}$ provides an example of a case in which a formal type of adjudication was held insufficient for strong deference. Ms. Hernandez petitioned for judicial review of the Bureau of Immigration Appeals' (BIA) decision denying her application for suspension of deportation under the Violence Against Women Act (VAWA), which created a mechanism for battered women to achieve lawful immigration status provided they can show, inter alia, that they "ha[ve] been battered or subjected to extreme cruelty in the United States by a spouse or a parent who is a United States citizen or lawful permanent resident." 150 Ms. Hernandez's husband beat her in Mexico; she fled to the United States; he tracked her down and, in the "contrite" phase of their abusive relationship, persuaded her to return to Mexico, where he once again abused her; and she fled again to the United States. ${ }^{151}$ The BIA rejected her subsequent application for a suspension of deportation because the acts of physical violence had occurred in Mexico; and therefore, she had not been "battered or subjected to extreme cruelty in the United States." 152 Before the Ninth Circuit, the BIA argued that its adjudicative interpretation of "extreme cruelty" was entitled to Chevron's strong deference. ${ }^{153}$

The Ninth Circuit rejected this contention in the following interesting passage:

149 Hernandez v. Ashcroft, 345 F.3d 824 (9th Cir. 2003).

150 Id. at 832 (citing 8 U.S.C. $\S 1254(\mathrm{a})(2)$ (2000)).

${ }^{151} \mathrm{Id}$. at 829-31.

152 Id. at 832.

${ }^{153}$ Id. at $827-28$. 
Although the Supreme Court has held that case-by-case adjudications under the INA [(Immigration and Naturalization Act)] may be subject to Chevron deference, there is no indication that the BIA intended to issue an interpretation of extreme cruelty in this case. The decision was not designated as precedential. Moreover, the BIA did not focus on the term or even reference its own regulation, and the opinion contains no definition or explicit consideration of the term. ${ }^{154}$

To the Ninth Circuit, the BIA's failure to identify its order as a precedent for internal agency purposes indicated that it had not intended to create a norm that would cut across cases, and thus function as generally applicable law. In one sense, this analysis is hardly surprising as it mirrors the treatment that the Supreme Court gave to the Customs ruling letter in Mead, which lacked any pretense to general applicability. ${ }^{155}$ In another sense, however, it obviously parts company with Mead as it denies Chevron deference to an interpretation produced through a formal type of procedure.

A case arising out of administration of the September 11th Victim Compensation Fund, Schneider v. Feinberg, ${ }^{156}$ provides a good illustration of how a norm's generality can serve as a sufficient condition for strong deference without regard to its procedural history. The Special Master of the Fund had, after notice-and-comment, promulgated a set of regulations creating a "sresumed award' scheme" and authorizing him to "develop a methodology and publish schedules, tables, or charts that will permit prospective claimants to estimate determinations of loss of earnings or other benefits." 157 The spouse of a decedent who had earned an exceptionally high income challenged these regulations on the ground that they created a de facto cap on awards in violation of the statutory mandate. In the course of its opinion rejecting this claim, the Second Circuit held that the compensation tables, though they had not been subjected to notice-and-comment, were entitled to Chevron deference because they were intended to apply generally to all claimants. Mead's proceduralism disappears from the scene:

${ }^{154}$ Id. at 839 n.13 (citation omitted) (emphasis added). See also Lagandaon v. Ashcroft, 383 F.3d 983, 987 n.2 (9th Cir. 2004) (observing in dicta that "[w]e have also indicated that nonprecedential BIA decisions might receive less deference than those designated as precedential"); Padash v. INS, 358 F.3d 1161, 1168 n.6 (9th Cir. 2004) (suggesting that strong deference should not apply to BIA's statutory construction that it applied in a formal adjudication because there was no evidence that this construction represented the agency's "reasoned and consistent" position).

155 See supra text accompanying notes 145-148.

156 Schneider v. Feinberg, 345 F.3d 135 (2d Cir. 2003).

${ }^{157}$ Id. at 140 (quoting 28 C.F.R. $\S 104.43$ (2000)). 
The touchstone is whether the agency interpretation is intended to carry the "force of law" (not whether it has been subjected to formal notice-andcomment procedures under the APA). Thus Chevron deference applies where the interpretation is "the type of legislative ruling that would naturally bind more than the parties to the ruling." Mead, 533 U.S. at 232.

The challenged regulations were adopted after a period of notice and comment, and are evidently intended to carry the force of law as to all claims submitted to the Fund. The accompanying tables were not subject to formal rule-making procedures, but they also exert force of law over all claims. Unlike opinion letters, interpretive rulings, agency manuals, and enforcement guidelines, the tables are "the type of legislative ruling that would naturally bind more than the parties to the ruling." Mead, 533 U.S. at $232 .{ }^{158}$

Together, cases such as Hernandez and Schneider demonstrate that, at least for some courts in some contexts, agency commitment to consistent interpretation is the key prerequisite for Chevron's strong deference. Their approach suggests the possibility that courts might use Occam's Razor to slice Mead's proceduralism out of deference analysis.

\section{E. Confusion on the Significance of Past Consistency}

The Supreme Court's recent treatment of longstanding agency interpretations further highlights the problematic nature of the relationship between agency interpretive consistency and strong deference. Oceans of pre-Chevron case law stood for the proposition that courts should defer to longstanding (i.e., old and consistent) constructions by agencies of statutes they administer. On the face of the matter, this sensible impulse does not fit well with either Chevron's celebration of interpretive flexibility or with Mead's focus on fictional delegations and procedure. Still, since Mead, the Court has in several opinions suggested that an agency can earn a form of strong deference for an interpretation by sticking to it consistently.

Differing majorities of the Court have offered two different justifications for this conclusion. The first has been to soften the edges of the Mead framework by suggesting that agency consistency can trigger (or at least help trigger) Chevron eligibility. The best example of this strategy appeared in Barnhart v. Walton, ${ }^{159}$ which turned on the definition of "disability" that the

158 Id. at 142-43 (citations and parentheticals omitted) (emphasis added).

159 Barnhart v. Walton, 535 U.S. 212 (2002). 
Social Security Administration uses to establish eligibility for benefits. ${ }^{160}$ The agency had adopted this definition no later than 1957, when it was stated in an opinion letter. ${ }^{161}$ Much later, and perhaps in response to the Walton litigation itself, the agency included this interpretation in a rule promulgated after notice-and-comment. ${ }^{162}$

All nine justices agreed that the notice-and-comment proceedings justified application of Chevron deference. ${ }^{163}$ Although it was analytically unnecessary to do so, Justice Breyer, writing for an eight-justice majority, also discussed at some length the significance of the interpretation's age as an alternative ground for triggering strong deference:

In addition, the Agency's regulations reflect the Agency's own longstanding interpretation. See Social Security Ruling 82-52, p. 106 (cum. ed. 1982); Disability Insurance State Manual $§ 316$ (Sept. 9, 1965); OASI Disability Insurance Letter No. 39 (Jan. 22, 1957). And this Court will normally accord particular deference to an agency interpretation of "longstanding" duration.

Finally, Congress has frequently amended or reenacted the relevant provisions without change. These circumstances provided further evidence-if more is needed-that Congress intended the Agency's interpretation, or at least understood the interpretation as statutorily permissible. ${ }^{164}$

Justice Breyer added that, even if the agency had not recently embedded its interpretation in a notice-and-comment rule, given the history and nature of that interpretation, it would still be entitled to Chevron's particular form of deference under Christensen and Mead:

[T]he Agency's interpretation is one of long standing. And the fact that the Agency previously reached its interpretation through means less formal than "notice and comment" rulemaking does not automatically deprive that interpretation of the judicial deference otherwise its due. If this Court's opinion in Christensen suggested an absolute rule to the contrary, our later opinion in Mead denied the suggestion ....

160 Id. at 214-15.

161 Id. at 219-20.

162 Id. at 221.

$163 \mathrm{Id}$. at 221-22; see also id. at 226 (Scalia, J., concurring in part).

${ }^{164}$ Id. at 219-20 (citations and parentheticals omitted or abbreviated) (emphasis added). 
In this case, the interstitial nature of the legal question, the related expertise of the Agency, the importance of the question to administration of the statute, the complexity of that administration, and the careful consideration the Agency has given the question over a long period of time all indicate that Chevron provides the appropriate legal lens through which to view the legality of the Agency interpretation here at issue. ${ }^{165}$

The short of the matter is that Justice Breyer journeyed far out of his analytical way to stress that an interpretation's longstanding status should count as an independent ground for triggering Chevron's particular strain of strong deference. ${ }^{166}$

This effort prompted Justice Scalia, ever the Chevron purist, to retort:

I do not believe, to begin with, that "particular deference" is owed "to an agency interpretation of 'longstanding' duration." That notion is an anachronism-a relic of the pre-Chevron days, when there was thought to be only one "correct" interpretation .... But once it is accepted, as it was in Chevron, that there is a range of permissible interpretations, and that the agency is free to move from one to another, so long as the most recent interpretation is reasonable its antiquity should make no difference.

If, however, the Court does wish to credit the SSA's [(Social Security Administration)] earlier interpretations-both for the purpose of giving the agency's position "particular deference" and for the purpose of relying upon congressional reenactment with presumed knowledge of the agency's position-then I think the Court should state why those interpretations were authoritative enough (or whatever-else-enough Mead requires) to qualify for deference. ${ }^{167}$

As Justice Scalia saw the matter, even if one granted that the Mead framework correctly limited Chevron's reach, the Court had failed to give a persuasive account of how that framework justified the extension of strong deference to agency interpretations that happened to reach a ripe old age. Given Mead's focus on extensive procedure as the presumptive means for

${ }^{165}$ Barnhart v. Walton, 535 U.S. 212, 221-22 (2002) (citations and parentheticals omitted or abbreviated) (emphasis added).

166 See also Utah v. Evans, 536 U.S. 452, 472 (2002) (suggesting that Census Bureau interpretation was entitled to Chevron treatment because it was longstanding and because Congress had acquiesced to it). $\mathrm{C} f$. id. at 487 ( $\mathrm{O}^{\prime}$ Connor, J., concurring in part, dissenting in part) (noting that majority failed to explain why agency interpretation enjoyed the "force of law").

167 Barnhart, 535 U.S. at 226-27 (Scalia, J., concurring in part) (citations omitted) (emphasis added). 
imbuing an interpretation with the "force of law," this contention had considerable force.

More recently, a narrower majority cloaked a longstanding agency statutory interpretation with Chevron's strength of deference even after holding that the Chevron doctrine itself was inapplicable. In $A D E C,{ }^{168}$ the Court addressed the EPA's power under the Clean Air Act's (CAA) Prevention of Significant Deterioration Program to block construction of a major air-pollutant emitting facility even after it had been permitted by state authorities. ${ }^{169}$ The agency had issued the relevant interpretation of a mix of CAA provisions back in $1983 .{ }^{170}$ Justice Ginsburg, writing for a five-justice majority, credited this interpretation as "longstanding." 71 Justice Breyer's strategy in Walton would seem to have left space for the Court, had it so chosen, to use the interpretation's age as a ground for triggering application of the Chevron doctrine per se. The majority instead held that, because the EPA's interpretation had only appeared in internal guidance memoranda, it lacked the "force of law" and was therefore ineligible for Chevron deference under Christensen and Mead. ${ }^{172}$ The interpretation was entitled only to Skidmore-type "respect."173

Under the usual understandings of the Chevron-Skidmore dichotomy, the majority's conclusion that Skidmore applied would indicate that the interpretive question properly before the Court was whether the EPA's statutory interpretation was the best one available-not whether it was rational. The majority, however, upheld the EPA's construction on the ground that the agency had "rationally construed" the statutory text. ${ }^{174}$ In short, the majority said that Chevron was inapplicable and then applied Chevron-strength rationality review anyway. The four-justice dissent took a dim view of this move:

So deficient are its statutory arguments that the majority must hide behind Chevron's vocabulary, despite its explicit holding that Chevron does not

168 Alaska Dep't of Envtl. Conservation v. EPA, 540 U.S. 461 (2004).

${ }^{169}$ Id. at $468-69$.

170 Id. at 487.

171 Id.

172 Id. at 487-88 (2004).

${ }^{173}$ Id. (citing Wash. State Dep't of Soc. and Health Servs. v. Guardianship Estate of Keffeler, 537 U.S. 371, 385 (2003)).

174 Alaska Dep't of Envtl. Conservation v. EPA, 540 U.S. 461, 485 (2004); see also id. at 488 (petitioner's arguments "do not persuade us to reject as impermissible EPA's longstanding, consistently maintained interpretation") (emphasis added); id. at 493 (stating that the EPA's "rational interpretation... is surely permissible") (emphasis added). 
apply. In applying Chevron de facto under these circumstances, however, the majority undermines the well-established distinction our precedents draw between Chevron and less deferential forms of judicial review. ${ }^{175}$

In both Walton and $A D E C$, the Court indicated that the longstanding status of an agency statutory construction can play a key role in triggering strong deference. These two cases reached this same end by twisting Mead in different ways. Walton does violence to Mead by minimizing its hard-edged proceduralism. $A D E C$ does so by mushing together Chevron and Skidmore review - two standards that Mead plainly presupposed were distinct. The Court's experiments with these approaches suggest both: (a) the dogged existence of a judicial impulse to extend strong deference to longstanding interpretations, and (b) that current doctrine has trouble accommodating this impulse in a clear way.

\section{F. Summary: The Relationship Between Agency Interpretive Consistency and Strong Deference Could Use Work, No?}

During the long pre-Chevron era, courts placed great value on agency interpretive consistency where it could exist meaningfully. ${ }^{176}$ This judicial taste for consistency is perfectly understandable given the courts' own stare decisis norms and the fact that consistency generates obvious rule-of-lawtype benefits. But then came Chevron, which advised that it is an excellent thing for modern agencies administering complex statutes to change interpretive course as new circumstances warrant. ${ }^{177}$ Picking up on this theme, cases like Smiley minimized the importance of agency interpretive consistency, holding that an agency can properly abandon an old interpretation provided that it has a reason for doing so that is sufficiently rational to survive arbitrariness review. ${ }^{178}$ First in Christensen, and then more emphatically in Mead, the Court made clear that not all interpretations by an agency of a statute it administers merit strong deference-only interpretations that enjoy the "force of law" should receive this favorable treatment. ${ }^{179}$ Chevron's celebration of agency flexibility would seem to suggest that an interpretation's possession of the "force of law" should not be

175 Id. at 517-18 (Kennedy, J., dissenting).

176 See supra Part II.A.

177 Chevron, U.S.A., Inc. v. Natural Res. Def. Council, Inc., 467 U.S. 837, 863 (1984).

178 See supra Part II.B.2 (discussing Smiley v. Citibank, N.A., 517 U.S. 735 (1996)).

179 See supra Part II.C. 
a function of consistency. On its surface, the Mead framework seems to agree with this view insofar as it made eligibility for strong deference a function of procedure. Mead's treatment of the Customs ruling letter at issue in that case, however, demonstrated the continuing vitality of the impulse to link strong deference to agency consistency. ${ }^{180}$ Post-Mead cases also show that judicial concern for agency consistency keeps bubbling through deference analysis. Some circuit court opinions have sliced away Mead's proceduralist overlay and have instead treated agency commitment to future uniformity as the touchstone for strong deference. ${ }^{181}$ In addition, some of the Supreme Court's own post-Mead opinions go far out of their analytical way to suggest that the fact that an interpretation is longstanding-and thus evidences past consistency-may trigger strong deference. ${ }^{182}$ This tension in the case law suggests the need for a framework for determining the scope of strong deference that confronts the import of agency consistency in a direct and clear way.

\section{RECONCILING THE VIRTUES OF INTERPRETIVE CONSISTENCY AND FLEXIBILITY}

Looking past its implicit-delegation fiction, Chevron teaches that resolving genuine ambiguity in an agency organic statute requires policymaking and that, generally speaking, politically accountable technocratic agencies are in a better position to make good policy choices than are generalist courts. ${ }^{183}$ Suppose that these claims of agency "interpretive" superiority have merit and that there are no countervailing advantages to judicial interpretation. From this supposition, it would seem to follow that courts should -if they wish to optimize policy outcomes-always defer to agencies' reasonable constructions of statutes they administer rather than displacing them with independent judicial constructions that are likely to be inferior. The functional logic of Chevron thus imposes a burden of justification on courts to explain their departures from the strong-deference model of review by identifying contexts in which judicial interpretation is likely to be better than agency interpretation.

As a threshold matter, a court cannot justify a preference for independent review based on its determination in a given case that its interpretation is substantively superior to an agency's different (but still reasonable)

180 See supra text accompanying notes 145-148.

181 See supra Part II.D.

182 See supra Part II.E.

183 Chevron, U.S.A., Inc. v. Natural Res. Def. Council, Inc., 467 U.S. 837, 864-66 (1984). 
interpretation. The agency is, according to the Chevron hypothesis, better able to make the policy judgments necessary to make such a determination correctly.

Given that substance cannot justify independent review, it is natural to consider whether procedure can. An agency's comparative interpretive advantages can only matter where an agency actually makes use of them-an interpretation that an agency bases on astrology, for instance, has little claim to anyone's respect. ${ }^{184}$ This point suggests that courts might justifiably engage in independent review where there are grounds for concluding that an agency has not done its interpretive "homework." As this determination cannot depend on the substantive merits of agency interpretation, this strategy naturally drifts toward scrutiny of agency process-for example, a court might ask whether the agency has taken procedural steps that ensure that its interpretation was the result of careful, politically transparent deliberation. This approach seems to be the core of Mead's proceduralist strategy for determining eligibility for strong deference. ${ }^{185}$ Mead's incoherence on the meaning of the "force of law" was discussed above. 186 The unpromising nature of its proceduralist strategy is discussed below.

Substance and procedure do not, however, exhaust the universe of potential justifications for independent judicial review of agency statutory constructions. Judicial glosses of agency organic statutes that are embedded in a common law system of precedent have the potential to foster benefits associated with the rule of law generally-for example, they can limit the discretion of executive authorities and thus decrease the potential for arbitrary decision-making, promote equality before the law, and allow regulated parties to identify stable legal norms. But then of course it is also the case that the agency interpretive discretion extolled by Chevron has virtues as well-for example, it permits agencies to change course as they learn from experience.

The commitment theory of deference identifies a category of interpretation in which the balance between these opposing virtues of judicial "law" and agency discretion seems relatively clear: Where an agency has made a substantial commitment to maintain a given statutory interpretation consistently, the agency reduces the marginal rule-of-law advantages to be gained from judicially-created limits on the agency's discretion. Where this

184 See Gary Lawson, Outcome, Procedure and Process: Agency Duties of Explanation for Legal Conclusions, 48 RUTGERS L. REV. 313, 318-19 (1996) (noting that the requirement that agencies give reasoned explanations for their decisions precludes policymaking by astrological divination).

185 United States v. Mead Corp., 533 U.S. 218, 230-31 (2001).

186 See supra text accompanying notes 134-148. 
condition holds, it is plausible to claim that the agency interpretive advantages of expertise and political accountability should trump the marginal rule-of-law advantages of judicial interpretation, and strong deference should apply. By contrast, if an agency is not sufficiently serious about its interpretation to commit to its general application, then courts can more easily justify imposing their own independent interpretations.

\section{A. Problems with Mead's Proceduralism}

Mead is a complex and confusing opinion that can be read a number of ways. One can, however, usefully think of it as an effort to answer the following question: How can an agency demonstrate that it exercised its expertise in fashioning a given interpretation and that it did so in a politically legitimate way? Put another way, how can an agency demonstrate that it made use of the comparative agency interpretive advantages identified by Chevron in developing a particular interpretation?

Mead's central answer seems to be that an agency can make this demonstration by subjecting a statutory construction to the travails of either notice-and-comment rulemaking or formal adjudication. ${ }^{187}$ In different ways and to differing degrees, both of these techniques require extensive agency effort and permit considerable public participation. Notice-and-comment rulemaking is politically open insofar as it allows any interested member of the public to participate by submitting a comment on a proposed rule. ${ }^{188} \mathrm{It}$ fosters agency deliberation because, to ensure that a rule survives judicial review for arbitrariness, an agency must respond to all significant comments submitted by the public. ${ }^{189}$

Formal adjudication functions much like a bench trial before a federal judge. Generally speaking, under the APA template, a regulated party subjected to such a proceeding has a right to notice of the basis for charges leveled against it, a chance to present evidence and marshal arguments for its position before an administrative law judge (ALJ), a chance to appeal the ALJ's decision to the agency itself, and a chance to appeal the agency's

\section{Mead, 533 U.S. at 230-31.}

1885 U.S.C. $\$ 553$ (2000). The degree to which notice-and-comment fosters meaningful public participation is, however, open to serious question. See, e.g., E. Donald Elliot, Re-Inventing Rulemaking, 41 Duke L.J. 1490, 1492 (1992) ("Notice-and-comment rulemaking is to public participation as Japanese kabuki theater is to human passions-a highly stylized process for displaying in a formal way the essence of something which in real life takes place in other venues.").

189 PIERCE, supra note $25, \S 7.4$, at $442-47$ (discussing and criticizing agency duty to respond to comments). 
decision to a federal court. ${ }^{190}$ The agency must justify all decisions with reasoned opinions, which fosters transparency and deliberation. 191

Mead seems to take the view that the use of such procedures demonstrates that an agency seriously deliberated over its position-thus exercising. whatever expertise it might possess - and that it did so in an open, relatively transparent way-thus enhancing the political legitimacy of its choice. ${ }^{192}$ Circling back to the congressional-intent fiction, because these sorts of interpretations demonstrably possess the qualities that make them worthy of the "force of law," it follows that these must be the interpretations that Congress wanted to have such force. ${ }^{193}$

This strategy of using procedural history to gauge whether an agency has earned strong deference for a given interpretation is problematic. ${ }^{194}$ For one thing, it is not self-evident that interpretations produced through Mead's favored devices are categorically "better" in some manner that is truly relevant to the applicability of strong deference than interpretations produced through other means. There is no reason, for instance, to think that an agency must use notice-and-comment or formal adjudication in order to exercise fully its policy expertise.

As for political accountability, certainly it is true that Mead's favored procedures call for considerable public participation and relative transparency - and these are not trivial virtues. It is not obvious, however, that interpretations devised without such procedures are so lacking in political legitimacy as to justify depriving them of strong deference. Indeed, Chevron's own recognition of the enhanced political legitimacy of agency, as opposed to judicial, interpretations seemed to flow from the fact that agencies, unlike courts, remain answerable to the political branches of government. ${ }^{195}$ This point holds regardless of which procedures an agency

190 See generally 5 U.S.C. $\S \S 554,556-57,701$ (a) (2000) (providing a template for formal adjudication; establishing default rule of judicial review).

191 5 U.S.C. § 557(c) (2000).

192 United States v. Mead Corp., 533 U.S. 218, 230-31 (2001).

${ }^{193}$ Id. ("It is fair to assume generally that Congress contemplates administrative action with the effect of law when it provides for a relatively formal administrative procedure tending to foster the faimess and deliberation that should underlie a pronouncement of such force.").

${ }^{194}$ Cf. Cass R. Sunstein, Chevron Step-Zero, supra note 74, at 32-33 (contending that, under its "best and most appealing reconstruction," Mead favors relatively formal procedures to foster "faimess and deliberation," but also noting that the "value of formal procedures ... might be questioned").

195 See Chevron, U.S.A., Inc. v. Natural Res. Def. Council, Inc., 467 U.S. 837, 865 (1984) (indicating that the political accountability of agencies flows from the fact that "[w]hile agencies are not directly accountable to the people, the Chief Executive is"). 
uses to promulgate any given policy. In a similar vein, Congress itself must not perceive a necessary connection between procedure and the legitimacy of agency power to act with the "force of law" because the APA permits agencies to promulgate certain categories of legislative rules without going through notice-and-comment. ${ }^{196}$

Moreover, even if one grants that an agency's use of Mead's favored procedures can help make up for the democracy deficit inherent in agency policymaking, treating notice-and-comment rulemaking and formal adjudication as equivalents in this respect seems strained at best. The quasilegislative notice-and-comment process is freely open to everyone who cares to submit a comment; the quasi-judicial process of formal adjudication, by contrast, necessarily. focuses on the parties present and is a much less pnlitically open endeavor. Mead does not provide an especially persuasive metric for measuring the political legitimacy of agency interpretations.

On a bigger-picture note, Mead's effort to use procedure to measure interpretive worthiness is difficult to square with venerable precedents holding that courts should not impose their own notions of ideal procedure on agency policymaking. For instance, it has been a point of hornbook law since SEC v. Chenery Corp. in 1947 that agencies with both rulemaking and adjudicative power have vast discretion to choose which to use to make policy. ${ }^{197}$ Similarly but more recently, the Court emphasized in Vermont Yankee Nuclear Power Corp. v. NRDC that courts should not, based on their own notions of what constitutes ideal procedure, impose additional requirements on the rulemaking process beyond those required by the Constitution or by statute. ${ }^{198}$ An important idea underlying such opinions is that agencies are in a better position than are courts to determine what sort of procedures make the most sense in a given policymaking context. ${ }^{199}$ This view is, at the very least, in tension with Mead's reliance on procedural categories to separate agency interpretations between Chevron-eligible wheat and the Skidmore chaff. ${ }^{200}$

1965 U.S.C. $\S 553(a)$ (2000) (exempting matters relating to the military, foreign affairs, or public property from APA rulemaking requirements); id. §553(b)(B) (providing a "good cause" exemption from notice-and-comment requirements).

${ }^{197}$ SEC v. Chenery Corp., 332 U.S. 194, 202-03 (1947). For a nuanced and critical examination of this principle, see M. Elizabeth Magill, Agency Choice of Policymaking Form, 71 U. CHI. L. REV. 1383, passim (2004).

198 Vermont Yankee Nuclear Power Corp. v. Natural Res. Def. Council., Inc., 435 U.S. 519, 541-49 (1978).

199 I PIERCE, supra note 25, § 6.9, at 377.

200 Admittedly, however, tension is not contradiction. See Krotoszynski, supra note 33, at 738 (noting that case law forbidding courts from creating new mandatory agency 
One might object, of course, to the preceding analysis on the ground that it grossly oversimplifies the complex Mead framework, which also states that Congress can signal its delegation of interpretative authority to an agency by means "other" than granting an agency the power to engage in notice-andcomment rulemaking and adjudication. ${ }^{201}$ Thus, Mead itself concedes that extensive procedure is not a necessary prerequisite for strong deference. If taken seriously, however, this concession causes Mead to hold something like the following: agency procedure is crucial for strong deference analysis except where it is not. The cost of saving Mead from the hard edges of its proceduralism is to empty it of much of its potential meaning.

In sum, Chevron acknowledges that agencies have certain technocratic and political strengths that they can bring to statutory construction. One can understand the Mead framework as a crude procedural test for ensuring that an agency has earned strong deference by actually bringing these strengths to bear in creating a given interpretation. Its treatment of procedure-at least with one side of its mouth - as the touchstone of strong deference tends to conflict with the Court's long-held view that the judiciary lacks the competence or authority to determine "ideal" agency policymaking procedures. Alternatively, to the degree that Mead does not take its own proceduralism seriously, perhaps no one else should either.

\section{B. The Commitment Strategy: Agency "Law" Reduces the Need for} Judicial "Law"

This subpart first discusses the role of independent courts in enforcing legislative constraints on executive discretion and in creating precedents that function as supplemental judicial constraints on such discretion. It then explores the commitment theory's approach to determining where courts should constrain agency discretion by exercising independent judgment concerning statutory meaning and where, by contrast, they should indulge strong deference-thus leaving agency discretion to choose among reasonable statutory meanings intact. This subpart then concludes by examining how the commitment theory might apply to various categories of agency interpretation.

\section{Judicial Interpretation and the Rule of Law}

By applying independent review to an agency's statutory construction rather than indulging Chevron-type strong deference, a court strips an agency

procedures does not forbid courts from "giving agencies an incentive to provide process in exchange for deference on review").

201 United States v. Mead Corp., 533 U.S. 218, 227 (2001). 
of a measure of interpretive discretion to make its organic statute mean what the agency wants it to mean. Both the separation-of-powers doctrine and the common law system of precedent support such judicial aggression insofar as they both regard limitations on official discretion as necessary for the rule of law, and they both regard the courts as devices for enforcing and creating such limits. It is also the case, however, that the executive officials of any functioning government must possess some minimal amount of discretion; moreover, in some contexts, it may make sense from a policy standpoint for executive officials to possess a considerable amount. So law (also known as limits on official discretion) is good, and discretion (also known as measured doses of lawlessness) is good, too, and there is no rigorous, bright-line means for determining their optimal balance.

Returning to fundamental principles, for the Framers, unlimited official discretion equated to tyranny. ${ }^{202}$ The rule of law blocks tyranny by creating meaningful limits on official discretion. By the late $1700 \mathrm{~s}$, two complementary systems had evolved in Great Britain for achieving a measure of such control: separation of powers among three distinct departments of government and the common law doctrine of precedent. The United States Constitution self-consciously adopted the former, and federal courts have always followed some form of the latter.

The Framers' great prophet of separation of powers was, of course, Montesquieu, ${ }^{203}$ who claimed that to block tyranny and allow political liberty to exist, "it is requisite the government be so constituted as one man need not be afraid of another." 204 To accomplish this end, it is necessary to distribute the three kinds of governmental power-legislative, executive, and judicial-among distinct actors:

When the legislative and executive powers are united in the same person, or in the same body of magistrates, there can be no liberty; because apprehensions may arise, lest the same monarch or senate should enact tyrannical laws, to execute them in a tyrannical manner.

Again, there is no liberty, if the judiciary power be not separated from the legislative and executive. Were it joined with the legislative, the life and liberty of the subject would be exposed to arbitrary control; for the judge

202 See, e.g., ThE FEderalist No. 47, at 307-08 (James Madison) (Robert Scigliano ed., 2000) (defining tyranny as " $[t]$ he accumulation of all powers, legislative, executive, and judiciary, in the same hands").

203 "The oracle who is always consulted and cited on this subject is the celebrated Montesquieu." Id. at 308.

2041 M. DE SEcondat, Baron de Montesquieu, The Spirit Of The Laws 163 (J.V. Prichard ed., Thomas Nugent trans., Fred B. Rothman \& Co. 1991) (1748). 
would be then the legislator. Were it joined to the executive power, the judge might behave with violence and oppression. ${ }^{205}$

Unpacking these aphorisms, the importance of separating legislative from executive power can be easily grasped by imagining their merger. If an executive official could make any "law" at will, then that official could give herself "legal" authority to do anything to anyone at any moment. A similar and only slightly less alarming effect would flow from combining legislative and judicial power, which would leave judges with arbitrary power to determine cases as they wish by making up laws to suit the whim of the moment. In either context, rule of (genuine) law cannot exist.

The analysis thus far gives an obvious explanation as to why it is important to separate legislative power from the enforcement powers enjoyed by the executive and judicial branches. It has not yet, however, explained why the power to enforce laws should be split between these second and third branches. Montesquieu, Blackstone, basic psychology, and common sense all suggest an obvious partial answer. In a chapter entitled, "That in Monarchies Ministers ought not to sit as Judges," Montesquieu charmingly explained:

There is in the very nature of things a kind of contrast between a prince's council and his courts of judicature. The king's council ought to be composed of a few persons, and the courts of judicature of a great many. The reason is, in the former, things should be undertaken and conducted with a kind of warmth and passion, which can hardly be expected but from four or five men who make it their sole business. On the contrary, in courts of judicature a certain coolness is requisite, and an indifference, in some measure, to all manner of affairs. ${ }^{206}$

Executive "heat" is beneficial as it implies a disposition to act with energy and dispatch-executive officials do not wait for problems to come to them but rather actively seek to implement the sovereign's will. ${ }^{207}$

It is a basic psychological fact of life, however, that desire affects judgment, and those who invest energy in a given course of action generally

205 Id.

$206 I d$. at 86.

207 Cf. THE Federalist No. 70, at 447-48 (Alexander Hamilton) (Robert Scigliano ed., 2000) ("Energy in the Executive is a leading character in the definition of good government."). 
wish to see it succeed.208 In this vein, Blackstone, the great guru of the common law during the early days of the Republic, observed that executive officials, given the chance, have a funny way of reading the law to suit the occasion when the need arises:

Were [the judicial power] joined with the executive, this union might soon be an over-balance for the legislative. For which reason, by the statute of 16 Car. I., c. 10. (Star-Chamber, 1640), which abolished the court of starchamber, effectual care is taken to remove all judicial power out of the hands of the king's privy council; who, as then was evident from recent instances, might soon be inclined to pronounce that for law, which was most agreeable to the prince or his officers. Nothing, therefore, is more to be avoided, in a free constitution, than uniting the provinces of a judge and a minister of state. 209

The proclivity of the executive's subordinates to see what they would like to see in the law has continuing relevance to this day and always will. For instance, as happens during times of war, the executive branch has interpreted its power expansively since $9 / 11$. As part of this effort, the Office of Legal Counsel prepared a memorandum explaining that the President's constitutional power as Commander-in-Chief trumps a statutory prohibition on torture. ${ }^{210}$ For obvious reasons, this memorandum has been the subject of political and legal controversy. The important point for the present is that, regardless of one's views of the memorandum's merits, it flags the danger of permitting executive actors-no matter how able, intelligent, and ethical-to determine their own powers.

The overarching lesson is that mere words on a piece of paper called statutes cannot, by themselves, constrain executive officials with active political will who control the power of the sword. To corral the executive with law, another force is needed-an independent, passive judiciary that operates in a political culture in which its judgments will stick. Its independence ensures that it does not kowtow to other powers and twist the law to fit the ends of the executive (or the legislature, for that matter). Its passive ("cool") institutional nature as an arbiter of controversies that others

208 See Mark Seidenfeld, Cognitive Loafing, Social Conformity, and Judicial Review of Agency Rulemaking, 87 CORNELl L. REV. 486, 504 (2002) (citing psychological literature on the "confirmation bias").

209 William BlaCKSTONE, 1 COMMENTARIES *270 (emphasis added).

210 Memorandum for Alberto R. Gonzales, Counsel to the President, Office of Legal Counsel (Aug. 1, 2002), in Mark DanNer, TORTURe and Truth: America, Abu GHRAIB, AND THE WAR ON TERROR, 142-49 (2004) ("Any effort by Congress to regulate the interrogation of battlefield combatants would violate the Constitution's sole vesting of the Commander-in-Chief authority in the President."). Id. at 149. 
bring to it helps reduce (although it obviously does not eliminate) the risk that it will decide outcomes in a result-driven manner to further an active political agenda. ${ }^{211}$ According to the basic separation-of-powers story, absent the efforts of this third branch without (much) political will of its own, laws enacted by a legislature cannot really constrain, and the rule of law must fail.

Having said this much about the virtues of law, it is also true that its opposite, discretion, is a necessary ingredient of any functioning government. ${ }^{212}$ Accordingly, Congress frequently enacts statutes that grant vast amounts of discretion to executive officials. Given that separation of powers presupposes legal limits on executive discretion to block tyranny, it is not surprising that courts purport to enforce a "nondelegation doctrine" to ensure that Congress does not give away too much of its legislative authority. The Supreme Court invoked this doctrine in 1935 to strike down portions of the National Industrial Recovery Act-a statute that, not to put too fine a point on the matter, gave President Roosevelt the power to regulate the American economy as he saw fit. ${ }^{213}$ The Court has not struck down any other statute on nondelegation grounds in the two-hundred-some years of its history, ${ }^{214}$ and the doctrine is widely regarded as a constitutional dead letter. ${ }^{215}$ One reason for its moribund state is that the Court has no good calculus for determining how much discretion is too much discretion, as Justice Scalia has observed:

Once it is conceded, as it must be, that no statute can be entirely precise, and that some judgments, even some judgments involving policy considerations, must be left to the officers executing the law and to the judges applying it, the debate over unconstitutional delegation becomes a

211 See Jonathan T. Molot, Reexamining Marbury in the Administrative State: A Structural and Institutional Defense of Judicial Power Over Statutory Interpretation, 96 Nw. U. L. REV. 1239, 1283-84, 1308 (2002) (discussing the passive nature of the courts as one of a set of institutional characteristics that suits the judiciary for the task of preserving the rule of law).

212 See, e.g., Gary Lawson, Delegation and Original Meaning, 88 VA. L. REV. 327, 338-39 (2002) (observing that "[ $t$ ] he operations of the executive and judicial powers inevitably entail some measure of discretion in application and interpretation. Indeed, this familiar 'gap-filling' role is perhaps the central task of the executive and judicial functions.").

213 A.L.A. Schecter Poultry Corp. v. United States, 295 U.S. 495, 541-42 (1935); Panama Refining Co. v. Ryan, 293 U.S. 388 (1935).

${ }^{214}$ Cass R. Sunstein, Is the Clean Air Act Unconstitutional?, 98 MICH. L. REV. 303, 332 (1999) (observing that 1935 was the nondelegation doctrine's "only good year").

${ }^{215}$ But see Cass R. Sunstein, Nondelegation Canons, 67 U. CHI. L. REV. 315, 315 (2000) (noting the common refrain that the nondelegation doctrine is dead; contending that it has found a new home in various canons of statutory construction). 
debate not over a point of principle but over a question of degree .... [I]t is small wonder that we have almost never felt qualified to second-guess Congress regarding the permissible degree of policy judgment that can be left to those executing or applying the law. 216

In short, limits on official discretion are necessary for the rule of law to exist, but we do not know with any precision where these limits should lie.

One inevitable aspect of executive discretion flows from the fact that any complex statute will be amenable to multiple reasonable interpretations. To the extent that a legislature leaves genuine ambiguities in a statute for later resolution, the legislature has not itself limited agency discretion. Thus, where a court applies strong deference and affirms an agency's rational construction of its own statute, the court may still be fairly said to have faithfully discharged its constitutionally-compelled, separation-of-powers function of ensuring that the agency remains within legislatively determined limits on its discretion.

When courts step beyond strong deference and exercise independent judgment to refine the meaning of agency organic statutes, they impose supplemental judicial limits on executive authority. Although separation of powers plainly demands the creation of legislative limits on executive authority and also requires an independent judiciary to enforce them, separation of powers does not demand (or forbid) the creation of such supplemental judicial limits on executive authority. ${ }^{217}$ Rather, the power to create and enforce the latter flows out of the common law's relatively grand conception of the courts' power to determine legal meaning.

In one sense, the common law system throws a great wrench in the basic separation-of-powers story as it authorizes courts to combine legislative and enforcement functions in the course of resolving cases. By definition, for the courts' de facto legislative power to operate without destroying the rule of law, there must be limits on judicial discretion to use it. One crucial limit is that courts are supposed to confine their lawmaking efforts to interstitial questions - they should decide no more law than is necessary to determine the outcome of a case. Another crucial limit is the doctrine of precedent, which, roughly speaking, limits judicial "legislative" discretion by requiring courts to apply the same legal rules today that they have applied in the past. This commitment to consistency fosters the rule of law by reducing the potential for arbitrary decision-making by later courts, requiring that

216 Mistretta v. United States, 488 U.S. 361, 415-16 (1989) (Scalia, J., dissenting).

217 See Barron \& Kagan, supra note 74, at 215 (observing aptly that "[t]he functions of policymaking and legal interpretation in the context of statutory ambiguity (the only context in which Chevron operates) are so intertwined as to prevent any strict constitutional assignment of the one to agencies and the other to courts"). 
similarly situated litigants receive equal treatment and creating more definite controlling norms which the governed can identify and then rely upon in planning their conduct. ${ }^{218}$

When applied to an agency organic statute, the judicial habit of determining "what the law is" for the purpose of resolving a case and then sticking to that construction in later cases tends to convert judicial statutory glosses into controlling norms that effectively limit agency discretion. ${ }^{219}$ The same types of rule-of-law benefits associated with judicial limitations on judicial discretion also of course flow from judicial limitations on executive discretion. The magnitude of the benefits of limiting executive discretion may be greater, however, given that the basic separation-of-powers story-line suggests that the "hot" executive is systematically more prone to arbitrary action than the "cool" courts. 220

Congress sometimes blocks the courts from creating definitive glosses on agency statutes by granting express (as opposed to fictional) authority to an agency to create legally-binding interpretations of its organic statute. ${ }^{221}$ And of course in Chevron itself, the Court disclaimed authority to create binding glosses that strip agencies of the power to choose among reasonable constructions of the statutes they administer. ${ }^{222}$ Determining under what circumstances courts should abandon the practice of creating such binding

218 See, e.g.; Payne v. Tennessee, 501 U.S. 808, 827 (1991) ("Stare decisis is the preferred course because it promotes the evenhanded, predictable, and consistent development of legal principles, fosters reliance on judicial decisions, and contributes to the actual and perceived integrity of the judicial process."). For a rich discussion of the institutional characteristics of courts that tend to limit their decision-making discretion and cause them to "strive for consistency in a way that political officials do not," see generally Molot, supra note 211 , at $1309,1292-1320$.

219 It bears noting that the Supreme Court very recently clarified the effects of judicial precedents on agency interpretative discretion in National Cable \& Telecommunications Association v. Brand X Internet Services, 125 S. Ct. 2688 (2005). In his Mead dissent, Justice Scalia had charged that, after a court announces its independent resolution of ambiguity in an agency's statute, "it becomes unlawful for the agency to take a contradictory position; the statute now says what the court has prescribed." United States v. Mead Corp., 533 U.S. 218, 247 (2001) (Scalia, J., dissenting). In Brand X, the Court rejected this contention, holding that an agency may use a Chevron-eligible interpretation to trump an earlier judicial precedent to the degree the latter purported only to resolve statutory ambiguity. Brand $X, 125 \mathrm{~S}$. Ct. at 2700 . See supra note 20 (noting interaction of Brand $X$ with this Article's "commitment" approach to strong deference).

220 See supra text accompanying note 206 (quoting Montesquieu's discussion of the implications of executive "heat" for allocation of judicial power).

221 See 29 U.S.C. $\$ 213(a)(15)$ (2000).

222 Chevron, U.S.A., Inc. v. Natural Res. Def. Council, Inc., 467 U.S. 837, 843, 863-64 (1984). 
glosses is problematic, however, for the same reason that Justice Scalia despaired of devising a nondelegation doctrine with teeth: It is impossible to determine with any pretense of rigor the optimal point at which the law should stop and discretion should start. 223

To summarize, both separation of powers and the common law presuppose that limits on enforcement discretion are absolutely necessary to the rule of law. The courts contribute to the rule of law both by enforcing legislative limits on executive discretion and by issuing opinions that function as supplemental judicial limits on executive discretion. Absent constitutional or legislative compulsion, courts perforce must decide for themselves when to impose such supplemental judicial limits on executive discretion.

\section{The Commitment Theory's Strategy for Balancing Judicial and Administrative Interpretive Advantages}

Given the indeterminacy of the inquiry, one can of course strike the balance between the virtues of agency discretion and judicial law in a number of plausible ways. For example, in accord with an extreme understanding of Chief Justice Marshall's dictum in Marbury that "[i]t is emphatically the province and duty of the judicial department to say what the law is," 224 one might adopt the view that the rule-of-law advantages of independent judicial review always trump those of agency discretion. Therefore, courts should always adopt the statutory constructions that they themselves deem best and, by so doing, block the potential for arbitrary executive manipulation.

In a more modern key, one might conclude that the advantages of agency interpretive discretion-at least when kept within rational limits-always trump the rule-of-law advantages of independent judicial construction. This understanding accords with Justice Scalia's view that Chevron's strong deference should apply to any reasonable authoritative construction by an agency of a statute it administers. ${ }^{225}$ Such deference still guarantees fidelity to the rule of law insofar as it strikes agency interpretations that contravene unambiguous congressional instructions. Unlike the Marbury approach, however, it does not create judicial glosses that block agencies from choosing among apparently rational statutory constructions. Rather, it merely polices against the possibility that agencies will make such choices arbitrarily by insisting that they give reasoned explanations for their interpretive

223 Mistretta v. United States, 488 U.S. 361, 415-16 (1989) (Scalia, J., dissenting).

224 Marbury v. Madison, 5 U.S. (1 Cranch) 137, 177 (1803).

225 United States v. Mead Corp., 533 U.S. 218, 241 (2001) (Scalia, J., dissenting). 
choices. It is perfectly plausible to suppose that this "broad Chevron" approach strikes the right balance between discretion and law by providing measured judicial scrutiny of administrative constructions while at the same time acknowledging that more aggressive judicial interference would be undesirable given the kind of complex policy judgments agencies must make to determine optimal statutory "meaning" in the modern administrative state. ${ }^{226}$ This approach to deference also carries the non-trivial advantage of conceptual simplicity-at least as compared to the creaky Mead-Chevron framework.

Eight justices of the Supreme Court have definitively rejected "broad Chevron," however, as overly permissive to agencies, ${ }^{227}$ and none adhere to the "extreme Marbury" approach suggested above. This state of affairs suggests a need to explore whether other coherent, readily administrable balancing points exist on the spectrum of judicial control to agency discretion.

The commitment theory lies at one such point. Sticking with the balancing metaphor, this approach's central insight is that when something is weighed against nothing, the scales always tip toward something. If one grants that the relevant advantages of independent judicial review flow from its potential to foster the rule of law by narrowing agency discretion and stabilizing governing norms, then it should follow that an agency can greatly reduce the marginal advantages of independent judicial review by imposing meaningful restraints on its own interpretive discretion. Put another way, where an agency's interpretation enjoys the force of generally applicable law because an agency has made a substantial commitment to applying it uniformly across time and parties, there is less value to be gained from judicial efforts to limit discretion and enforce consistency. Where there is less value to independent judicial review, courts should feel freer to apply a relatively lax form of rationality review to an agency's construction of a statute it administers. By contrast, where an agency cannot demonstrate its commitment to consistency, the commitment theory parts from broad Chevron by counseling that courts should adopt the statutory interpretation that they themselves deem best after giving due respect to agency views on the subject-that is, courts should apply the principles of so-called Skidmore deference.

Of course, the concept of agency "commitment" needs explication. At the outset, it is important to take heed of Chevron's admonition that agency

226 For an argument to this effect, see Jordan, supra note 121 , at 727-30 (contending that Chevron's step-two rationality review, properly understood, provides sufficient protection against arbitrary agency action).

227 Mead, 533 U.S. at 235-39. 
interpretations are not "carved in stone" the moment they are made. ${ }^{228}$ Given that this premise is deeply embedded in modern administrative law and normatively attractive to boot, the commitment theory cannot credibly demand that an agency give up all power to change interpretive course of its own accord as the price for strong deference. There is, however, nothing selfcontradictory in the idea that an entity can commit to a course of action yet retain some power to change it. Nor, for that matter, is an agency's retention of the power to change an interpretation it creates necessarily inconsistent with the proposition that the interpretation carries the "force of law" in some relevant sense-for example, statutes are laws even though Congress can change them. "Commitment" is a matter of degree.

How then, can an agency demonstrate sufficient commitment to an interpretation to trigger strong deference? Broadly speaking, the underlying rationales for caring about agency commitment are that it can help demonstrate that: (a) an agency has not selected a statutory construction arbitrarily to disadvantage a particular regulated party, and (b) the interpretation instead constitutes a generally applicable norm upon which interested persons can rely. In general, there are two ways in which an agency ought to be able to convince a court (and regulated parties) that an interpretation has sufficient stability and generality to alleviate such concerns. First, the agency might demonstrate its commitment to a current interpretation by proving that it has consistently maintained this interpretation in the past. This method obviously.will not work for new or changed interpretations. To demonstrate commitment to a new interpretation, an agency must demonstrate that it has somehow given up a measure of its discretion to change that interpretation in the future. Put another way, a new interpretation carries with it an expectation of uniformity if it will be sufficiently hard for the agency to change it later. In this vein, note that although Chevron holds that agencies ought to be able to change interpretive course, it does not hold that it must be easy to do so.

\section{a. The Easy Case for Strong Deference to Longstanding Agency}

\section{Interpretations}

Perhaps the strongest evidence an agency can provide that it has committed to general application of a given interpretation is that the agency has in fact maintained it consistently in the past. Suppose for instance that an agency has applied a given statutory construction to regulated parties $A$ through $Y$ over some period of years. The agency then applies the very same

${ }^{228}$ Chevron, U.S.A., Inc. v. Natural Res. Def. Council, Inc., 467 U.S. 837, 863 
construction to similarly situated party $Z$. It is of course conceivable that the agency's treatment of $Z$ was arbitrary in the sense that the agency had developed a secret preference for a different statutory construction that would have been more favorable to $Z$ but then stuck to its obsolete interpretation in order to reach a result unfavorable to $Z$. To put the matter mildly, however, this scenario does not seem likely. Rather, the agency's history of consistency suggests that it subjected $Z$ to a generally applicable norm and, furthermore, that $Z$ ought to have been able to predict this result. In such a situation, a court would add little in the way of rule-of-law value by trumping the agency's longstanding construction with an independent judicial interpretation.

The commitment theory thus provides an extremely obvious and direct rationale for the proposition that courts should apply strong deference to longstanding consistent agency interpretations. ${ }^{229}$ This conclusion accords well with the vast number of cases from the pre-Chevron era which indicated that courts should defer to longstanding agency interpretations so long as they were reasonable. ${ }^{230}$ It also relieves the embarrassment-illustrated in recent years by cases such as $A D E C$ and Walton-that the Mead framework has trouble justifying this sensible judicial impulse. ${ }^{231}$

\section{b. Demonstrating Commitment to a New Interpretation via Legislative Rule}

By hypothesis, an agency cannot offer a history of consistent interpretation to support a new (or changed) interpretation. Obviously, an agency cannot demonstrate its commitment to a new interpretation simply by claiming that it really means it. For one thing, it is not clear what it would mean for an agency-composed of many people and with a leadership that often changes quickly - to possess such a subjective intent. For another, exploration of the subjective intent of agency leadership might require judicial investigation of administrative "mental processes". of a sort that courts have long disfavored. ${ }^{232}$

It follows that agencies must demonstrate commitment with some form of objective evidence that an interpretation is reasonably likely to persist and

229 Of course, because the adjective "longstanding" is fuzzy, determining when an interpretation has attained this status calls for evaluative judgment, but courts seem to have had little trouble making such judgments in the past. See supra Part II.A.1 (discussing deference to longstanding interpretations in the pre-Chevron case law).

.230 See id.

231 See supra Part II.E (discussing the Supreme Court's post-Mead treatment of deference to longstanding agency interpretations).

232 PIERCE , supra note $25, \S 8.6$, at 553-58. 
have general application. An interpretation is more likely to have such general application where there are significant barriers that curb an agency's discretion to change interpretive course. In other words, an agency should be able to demonstrate its commitment to a new interpretation by persuading a court that the agency will find it (at least somewhat) hard to alter.

It will be relatively hard for an agency to change an interpretation when it must use costly procedures to do so. This observation flows out of a broader point relating to the importance of what might be called "procedural stickiness" to the rule of law. Where a legislative authority (a category that includes many modern agencies) can freely and instantaneously create any "law" it likes to suit the moment, the rule of law will tend to collapse into the rule of whim. Suppose, for instance, that Congress had perfect knowledge of cases proceeding through the courts and could change the law instantaneously and without cost to suit the whim of any momentary majority. Under such a circumstance, the law would tend to become whatever it needed to be to ensure that cases reached legislatively determined outcomes. Law would lose its generality, and the rule of law its meaning. Quite aside from any constitutional limits on these sorts of shenanigans, they tend not to happen because, given its size, bicameralism, presentment requirements, etc., it is hard for Congress to legislate. ${ }^{233}$ Thus procedural stickiness, by increasing the stability of the law, enhances its rule.

Agency rulemaking procedures contain a notorious source of such procedural stickiness. The APA contemplates a variety of types of rules; the two most important for the present discussion are "legislative" and "interpretative." Legislative rules, as their name suggests, enjoy the "force of law" in the sense that they are binding on regulated parties, agencies themselves, and the courts as well (provided they survive strongly deferential review). ${ }^{234}$ Interpretative rules merely purport to explain the meaning of preexisting law rather than to create new binding requirements. ${ }^{235}$ This distinction has important procedural implications. The default mode for promulgating a legislative rule is notice-and-comment, which can be

233 Congressional intervention in the Schiavo proceedings is the exception to this point that proves the rule. See Schiavo ex rel. Schindler v. Schiavo, 404 F.3d 1270, 1271 (11th Cir. 2005) (Birch, J., concurring) (contending that congressional efforts to direct the outcome of the Schiavo case violated separation of powers).

234 PIERCE , supra note 25, § 6.4, at 324-25.

235 Syncor Int'l Corp. v. Shalala, 127 F.3d 90, 94 (D.C. Cir. 1997). 
famously time-consuming and expensive. ${ }^{236}$ By contrast, the APA leaves agencies free to adopt interpretative rules more or less at will. ${ }^{237}$

Given that an agency's statutory constructions are, after all, interpretations, it is obvious enough that agencies should be free to promulgate them as "interpretative rules," within the meaning of the APA, that are free of onerous procedural requirements. Mead, however, makes clear that agencies with legislative rulemaking authority can use notice-andcomment to imbue their interpretations with the "force of law" enjoyed by a legislative rule. ${ }^{238}$ In other words, agencies can apply their legislative authority to the task of interpretation-thus winning strong deference for their interpretations in the process. ${ }^{239}$

But what justifies this favorable judicial treatment of interpretations vetted through notice-and-comment? The judicial conclusion that agencies can give their interpretations legislative force was hardly inevitable; at one point in time the Court could have easily avoided it by taking a page out of Marbury and declaring interpretation the inviolate "province" of the courts. ${ }^{240}$ Recall that in Mead, the Court justified its favorable treatment of select categories of agency interpretation with an extraordinarily strained story of congressional intent. According to this story, it makes sense for interpretations promulgated through notice-and-comment-the default mode for producing legislative rules-to receive strong deference because this technique is such a good way to make binding legal norms as it encourages agency deliberation and broader public participation. Because notice-andcomment is so good, it follows that Congress, which we may presume likes

2365 U.S.C. $\S 553(2000)$. For a discussion of the trying nature of modern noticeand-comment rulemaking, see, for example, Pierce, supra note 26, at 59-66.

237 See 5 U.S.C. $\$ 553$ (2000) (exempting interpretative rules from notice-andcomment requirements).

238 United States v. Mead Corp., 533 U.S. 218, 229 (2001).

${ }^{239}$ As a number of scholars and courts have observed, the strongly deferential arbitrariness review owed to legislative rules is basically equivalent to Chevron's rationality review. See Levin, supra note 74, at 1254 (analogizing Chevron step-two to arbitrariness review); Seidenfeld, supra note 74 , at 128-29 (similar); Jordan, supra note 121 , at 727 (similar).

240 Marbury v. Madison, 5 U.S. 137, 170 (1803); see also NLRB v. Hearst Publ'ns., Inc., 322 U.S. 111, 130 (1944) (reserving for the courts the power to resolve questions of statutory interpretation). Also, it bears noting that the APA itself arguably lends support to the view that courts should exercise primary interpretive power over ambiguous agency statutes as it instructs courts to "decide all relevant questions of law [and] interpret ... statutory provisions." 5 U.S.C. $\$ 706$ (2000). See, e.g., Barron \& Kagan, supra note 74, at 218 (noting and criticizing this argument). 
good things, must intend for interpretations produced through notice-andcomment to possess the "force of law."241

The commitment theory of deference has a much simpler explanation as to why, generally speaking, it makes sense for courts to construe agency legislative authority as extending to interpretation and to apply strong deference to the results: again, a legislative rule binds the agency that produces it until the agency creates another legislative rule to change it. ${ }^{242}$ Where an agency embeds an interpretation in a legislative rule and the default mode for changing that interpretation requires notice-and-comment, an agency makes a demonstrable commitment to retaining its interpretation for some period of time if only because it will likely be costly to change. Such commitment reduces the probability of arbitrary manipulation of statutory meaning and enhances the stability of the interpretation, thus enhancing the rule of law and reducing the need for independent judicial review.

The flip-side of this analysis offers a neat explanation for the results in Christensen and Mead, which both involved review of statutory interpretations that the challenged agencies were free to abandon with little ceremony. Recall that in Christensen, a narrow majority of the Court concluded that an opinion letter drafted by an administrator for the Wage and Hour Division of the Department of Labor was not entitled to Chevron's strong deference. ${ }^{243}$ This opinion letter was in the nature of an interpretative rule. In theory, the same administrator could have written a second opinion letter renouncing the earlier one the very next day; and, if such opinion letters were subject to strong deference, then a reviewing court should have upheld it so long as the agency gave a minimally rational explanation for the change. Of course, one practical limitation on an agency's power to make such a move is that courts, no matter how weak the ostensible standard of review, tend to view flip-flopping as a red flag inviting greater scrutiny. The fact remains, however, that a newly-drafted opinion letter does not, in itself, amount to nearly as much evidence of agency commitment as a legislative rule.

Mead itself provides a textbook opportunity for application of the commitment theory. As the Supreme Court observed, Customs' regulations provided that its ruling letters were "subject to modification or revocation without notice to any person, except the person to whom the letter was

241 Mead, 533 U.S. at 230-31.

242 PIERCE , supra note $25, \S 6.4$, at 324-25.

243 Christensen v. Harris County, 529 U.S. 576, 586-87 (2000). 
addressed."244 Where an agency goes out of its way to emphasize its freedom to jettison its rulings at any time, it is easy to justify the conclusion that courts should not defer to such rulings as statements of binding "law."

\section{c. Demonstrating Commitment Without a Legislative Rule}

Again, the key to the commitment theory as applied to new interpretations is that, to justify strong deference, an agency must demonstrate that it will take significant energy to change interpretive course. An initial interpretation need not itself be embedded in a legislative rule per se for this condition to hold. For instance, an agency's organic statute might require significant procedural effort to change an interpretation even if that interpretation was not itself adopted as a legislative rule. Alternatively, an agency could impose such requirements for interpretive change on itself by regulation. Interestingly enough, Mead illustrates both of these possibilities.

After Customs issued the ruling letter in question in Mead, Congress took legislative steps to reduce the room for arbitrariness in this regulatory regime. In essence, this legislation provided that, although Customs could issue an initial ruling letter without notice-and-comment, it would have to use a form of notice-and-comment before issuing a new ruling letter that modified or revoked an interpretation contained in a preceding one. ${ }^{245}$ of course, not all rounds of notice-and-comment are created equal. While this process tends to be onerous in major, controversial rulemakings (e.g., the FDA's attempt to regulate tobacco ${ }^{246}$ ), it is obviously less so for relatively trivial issues of narrow concern-for example, whether day-planners are "bound diaries." This process always requires agency attention and energy, however, and, to avoid this expense, an agency will have an incentive to stick to a position it states in an initial ruling letter rather than change it.

Note also that an agency itself can create such limits on its interpretive discretion by promulgating appropriate procedural rules. For instance, even before the legislation just discussed was enacted, Customs regulations provided that notice-and-comment procedures had to be used for ruling letters that would have the "effect of changing a practice." 247 As it happened,

244 United States v. Mead Corp., 533 U.S. 218, 223 (2001) (quoting 19 C.F.R. $\S 177.9(\mathrm{c})(2000))$.

245 See 19 U.S.C. $\S 1625$ (c) (2000) (quoted and discussed in Mead, 533 U.S. at 223 n.3, 234).

246 See FDA v. Brown \& Williamson Tobacco Corp., 529 U.S. 120, 126-27 (2000) (noting that the FDA received 700,000 comments during a rulemaking effort to regulate tobacco as a drug).

247 See 19 C.F.R. § 177.10(c) (2000) (noted in Mead, 533 U.S. at 223 n.2). 
the Federal Circuit ruled this exception inapplicable to the facts of Mead. ${ }^{248}$ Notwithstanding this result, this regulation illustrates the general proposition that an agency can use its rulemaking authority to increase the cost of changing its statutory interpretations. On a commitment approach, this conclusion leaves agencies with considerable power to ensure that courts will extend strong deference to their interpretations regardless of the means used to produce them originally-it is just that an agency must pay a price in interpretive commitment to obtain this treatment.

\section{d. Adjudications-Reviving Hearst}

Mead indicated that interpretations embedded in orders produced through formal adjudication generally can enjoy the "force of law" and be Chevron eligible. $^{249}$ The problem with this stance from the point of view of the commitment theory is that an agency can abandon a statutory interpretation adopted via a formal adjudication in any number of ways-some of which are quite cheap. In theory, an agency could announce such a change by issuing a new interpretative rule with little or no procedural ado. Alternatively, an agency could of course announce its change of position in a new formal adjudication directed at some regulated party. Note that, in such a context, even if the formal adjudicative proceedings are themselves somewhat costly, the agency's incremental procedural cost of changing its interpretation during these proceedings would be negligible. The upshot of these possibilities is that a construction announced in a formal adjudication does not have that much more "binding effect" on an agency than the Customs ruling letter that the Court held in Mead lacked the "force of law" and which the agency was free to abandon at any time. ${ }^{250}$ The commitment theory therefore counsels that a novel statutory construction should not

248 Mead Corp. v. United States, 185 F.3d 1304, 1307 n.1 (Fed. Cir. 1999).

249 See United States v. Mead Corp., 533 U.S. 218, 230-31 (2001).

${ }^{250} \mathrm{Id}$. at 231-33. For evidence of the lack of binding force on agencies of their own formal adjudications, the following sampling of recent NLRB decisions may be instructive: Crown Bolt, Inc., 343 N.L.R.B. No. 86 (Nov. 29, 2004) (overruling, inter alia, Springs Indus., 332 N.L.R.B. 40 (2000)); H.S. Care L.L.C., 343 N.L.R.B. No. 76 (Nov. 19, 2004) (overnuling M.B. Sturgis, Inc., 331 N.L.R.B. 1298 (2000), which overruled Lee Hosp., 300 N.L.R.B. 947 (1990)); Brown Univ., 342 N.L.R.B. No. 42 (July 13, 2004) (overruling New York Univ., 332 N.L.R.B. 1205 (2000), which overruled Leland Stanford Junior Univ., 214 N.L.R.B. 621 (1974)); IBM Corp., 341 N.L.R.B. No. 148 (June 9, 2004) (overruling Epilepsy Found. of Northeast Ohio, 331 N.L.R.B. 676 (2000), which overruled E.I. DuPont \& Co., 289 N.L.R.B. 627 (1988), which, in light of a judicial opinion, modified Sears, Roebuck \& Co., 274 N.L.R.B. 230 (1985), which had overruled Materials Research Corp., 262 N.L.R.B. 1010 (1982)). 
receive strong deference merely because it was incorporated into a formal adjudication for which an agency claims the "force of law."

At first glance, this conclusion may seem like very strong medicine because it would require abandonment of a many-decades-old practice of applying strong deference to the results of at least some formal adjudications. But the commitment theory would not compel this result because its logic leaves space for application of the Hearst strain of deference doctrine from the pre-Chevron era. ${ }^{251}$ Recall that in Hearst, the level of deference hinged on whether an agency had resolved a "pure" question of law or a "mixed" question of law and fact. The distinction between the two categories is fuzzy and easy to manipulate, but the core idea is that a pure question is abstract and can be determined without reference to the facts of a case; a mixed question, by contrast, determines whether a given legal term applies to some set of specific facts. ${ }^{252}$ For example, in Hearst, the NLRB resolved the mixed question of whether newsboys, given their specific work conditions, were "employees." 253 Similarly, a jury determines a mixed question whenever it decides whether a defendant's specific conduct was "negligent." 254 Mixed questions occupy the border between fact and lawindeed, when courts wish to stress the factual ingredient of such questions, they refer to them as "ultimate questions of fact."255

An agency's commitment to general application of a norm is of most concern where that norm lends itself to application in a variety of contexts. Recalling Hearst yet again, the Court's ruling that the NLRA does not incorporate by reference the common law definition of "employee" had obvious potential for wide-ranging impact across innumerable cases. ${ }^{256} \mathrm{By}$ contrast, where a mixed question merely determines that a particular set of facts is captured by a given legal term, it is far less clear what it would mean to apply the determination "consistently" in a different case with a different set of particular facts. ${ }^{257}$ This is not to deny, of course, the potential for

251 See supra Part II.A.2 (discussing the deference doctrine of NLRB v. Hearst Publications., Inc., 322 U.S. 111 (1944)). For an excellent review of the case law history of judicial deference as well as a powerful argument claiming that the Supreme Court has never really abandoned the Hearst model of deference, see Reese, supra note 31.

252 See supra text accompanying notes 57-65.

253 Hearst, 322 U.S. at 130-32.

254 Thomas v. Gen. Motors Acceptance Corp., 288 F.3d 305, 307 (7th Cir. 2002).

255 Id.

${ }^{256}$ See Hearst, 322 U.S. at 128-29 (holding that "employee," as used by the NLRA, did not incorporate common law definitions).

257 Cf. Thomas, 288 F.3d at 307 (observing that, given the fact-sensitive nature of mixed-questions, "uniformity of outcome is unattainable; and as divergent applications of 
resolutions of mixed questions to serve as precedents in later cases. It is, however, to say that, generally speaking, the more fact-sensitive a determination, the less amenable it is to creation of a general rule of broad impact.

The preceding analysis suggests that the commitment theory of strong deference might coexist with the Hearst mixed-question type of analysis. The former instructs courts to extend strong deference to an agency's "pure" construction of a statute it administers so long as the agency can provide objective evidence that the construction has or will be generally applied. The latter instructs that a court need not require evidence of such commitment before extending deference to an agency's resolution of a highly factsensitive, mixed question because, by hypothesis, consistency does not pose so great a concern in such a context. The result of this combination is that an agency could claim a form of strong deference for its resolution of a mixed question via adjudication (whether formal or informal), but not for a pure statutory construction produced via adjudication absent evidence of commitment to its general application.

One benefit of such an approach would be that it would encourage agencies to channel their resolution of broad, pure questions of statutory construction away from adjudication and toward rulemaking - which many scholars have long contended provides the superior method for making policy. ${ }^{258}$ One might object that this effect would violate the venerable administrative law principle that an agency ought to be able to choose freely whether to make its policy choices via adjudication or rulemaking. ${ }^{259}$ This objection dissolves at least partially upon consideration of some of the

law to fact do not unsettle the law--doctrine is unaffected-a heavy appellate hand in these cases is unnecessary to assure the law's clarity and coherence").

${ }^{258}$ See generally PIERCE, supra note $25, \S 6.8$, at 368-74 ("Over the years, commentators, judges, and Justices have shown near unanimity in extolling the virtues of the rulemaking process over the process of making 'rules' through case-by-case adjudication."). For a recent argument that administrative law should channel agency policymaking toward rulemaking, see generally Bressman, supra note 24 , at 530-53.

${ }^{259}$ See SEC v. Chenery Corp., 332 U.S. 194, 202-03 (1944). One might also object that the suggestion that courts should encourage rulemaking runs counter to this Article's earlier critique of Mead's proceduralism. Cf. supra text accompanying notes 197-199. There is, admittedly, a tension. Note, however, that, unlike Mead, the present suggestion builds on the prevalent idea that, at least in those contexts where a policy problem is amenable to a uniform solution, rulemaking provides a better means for making policy than does formal adjudication. See supra note 258 and accompanying text. It also attempts to address the concerns that have led courts to eschew efforts to promote rulemaking over adjudication. See infra text accompanying note 260 . Mead, by contrast, fails to offer a coherent explanation for favoring both rulemaking and formal adjudication and treating them as rough equivalents for the purpose of deference analysis. See supra text following note 196. 
reasons the Court has given for leaving agencies with such discretion. For instance, in NLRB v. Bell Aerospace Co., the Court observed that it was important to leave agencies with discretion to make policy via adjudication because: (a) sometimes an agency has not learned enough about a problem to craft a well-designed, bright-line rule that cuts across cases; or (b) in other contexts, a problem "may be so specialized and varying in nature as to be impossible of capture within the boundaries of a general rule." 260 Where an agency announces a "pure" statutory construction via formal adjudication, however, it has, by definition, announced an abstract, general rule that cuts across cases. It has, in other words, announced a legal norm that could very well have been produced via rulemaking — and therefore — other things being equal—perhaps should have been.

\section{CONCLUSION}

Current judicial deference doctrine fails to give a coherent account of the balance between the virtues of interpretive consistency and flexibility. A vast amount of pre-Chevron case law placed a high value on the former, which has obvious rule-of-law virtues. Chevron itself extolled the latter, which allows agencies to change interpretive course on the basis of new learning. Confusion with regard to how to reconcile these competing values is perfectly understandable given that there is no determinate formula for striking an optimal balance between them. Still, there are coherent, plausible ways of thinking about this balance. One of them is the commitment theory, which counsels that courts should extend strong deference where an agency can demonstrate that it has committed to general application of its statutory construction - thus imbuing it with what might fairly be called the "force of law." Generally speaking, an agency can demonstrate its commitment to an interpretation either: (a) by documenting that it has consistently adhered to it in the past (i.e., the interpretation is longstanding); or (b) by demonstrating that it has limited its discretion to part from the interpretation in the future (e.g., because it will be costly to do so). The logic behind this approach is that, where such agency commitment exists, courts can add little in the way of marginal rule-of-law value by imposing their own independent statutory constructions. This conclusion frees courts to indulge the premise of strong deference - the best way to determine the "meaning" of an agency's organic statute is to ask the agency.

260 NLRB v. Bell Aerospace Co., 416 U.S. 267, 292-95 (1974) (citing Chenery Corp., 332 U.S. at 202-03). 